Boletín de la Sociedad Geológica Mexicana

VOLUMEN 65, NÚM. 2, 2013, P. 373-395

\title{
Provenance and tectonic setting of Neoproterozoic to Early Cambrian metasedimentary rocks from the Cordillera Oriental and Eastern Sierras Pampeanas, NW Argentina
}

\author{
Aránzazu Piñán-Llamas, ${ }^{1, *}$, José C. Escamilla-Casas² \\ ${ }^{1}$ Indiana University-Purdue University Fort Wayne, 2101 E. Coliseum Blvd. Fort Wayne, IN 46805. Phone: (260) $481-6253$. \\ ${ }^{2}$ Universidad Autónoma del Estado de Hidalgo. Área Académica de Ciencias de la Tierra y Materiales. Ciudad Universitaria Carretera \\ Pachuca - Tulancingo Km. 4.5 C.P. 42184. Col. Carboneras, Mineral de la Reforma, Hidalgo. Phone: 017717172000. \\ *pinana@ipfw.edu
}

\begin{abstract}
Major, trace, and rare-earth element data for the Neoproterozoic to early Cambrian Puncoviscana Formation and related highergrade metasedimentary rocks in Eastern Sierras Pampeanas, NW Argentina, were analyzed to evaluate their provenance, weathering, and tectonic setting during the upper Neoproterozoic-lower Paleozoic. The studied rocks are metapelites and metapsammites that were mainly affected by the lower Cambrian Pampean orogeny. Geochemical analyses indicate that the Puncoviscana Fm. and related rocks are characterized by moderate Chemical Index of Alteration (CIA) values. REE element distributions, Eu/Eu* values, and high $\mathrm{Zr} / \mathrm{Sc}$ and $\mathrm{Th} / \mathrm{Sc}$ ratios indicate that the samples were likely derived from predominantly upper-crust felsic sources. Tectonic discrimination diagrams based on immobile trace elements (e.g. Th-La-Sc, Sc-Th-Zr/10), multi-element patterns, REE characteristics, and diagnostic trace element ratios (i.e. $\mathrm{Th} / \mathrm{Sc}, \mathrm{Zr} / \mathrm{Hf}, \mathrm{La} / \mathrm{Th}, \mathrm{La} / \mathrm{Sc}$ ) imply that the tectonic setting of the source area was a continental island arc and/ or an active continental margin. Geochemical signatures of low-grade metapsammitic samples (high $\mathrm{Hf}$ and $\mathrm{Zr}$ content, and high $\mathrm{Zr}$ / Sc ratios) indicate crustal recycling.

The geometry and sequence of structures and microstructures preserved in all samples are pervasive and suggest a common and uniform deformational history during the Pampean orogeny. Geochemical signatures and structures of the studied samples are consistent with protolithic sediments of the Puncoviscana Fm. and related rocks initially deposited in an arc-related basin that was subsequently deformed during the Pampean orogeny.
\end{abstract}

Keywords: Geochemistry, metasedimentary rocks, provenance, Pampean orogeny, Puncoviscana Formation.

\section{Resumen}

En este estudio, se caracteriza la proveniencia, grado de alteración, y el ambiente tectónico de rocas metasedimentarias de edad Neoproterozoica a Cámbrico Temprano del NW de Argentina, (Formación Puncoviscana y rocas equivalentes de mayor grado metamórfico aflorantes en las Sierras Pampeanas Orientales) durante el Neoproterozoico superior al Paleozoico inferior, en base al análisis de datos de elementos mayores, trazas, y tierras raras. Las rocas analizadas son metapelitas y metapsamitas que fueron afectadas principalmente por la orogenia Pampeana (Cámbrico Inferior). Los resultados geoquímicos indican que estas rocas se caracterizan por presentar valores moderados en el Índice Químico de Alteración (CIA). Las distribución de tierras raras, y los valores de Eu/Eu*, $\mathrm{Zr} / \mathrm{Sc}, y \mathrm{Th} / \mathrm{Sc}$ indican que las muestras se derivaron muy probablemente y de forma predominante, de rocas fuente félsicas de la corteza superior. Diagramas de discriminación tectónica basados en elementos traza inmóviles (e.g. Th-La-Sc, Sc-Th-Zr/10), patrones multielementos, características de las tierras raras y relaciones de elementos traza útiles en la discriminación del ambiente tectónico (i.e. Th/Sc, $\mathrm{Zr} / \mathrm{Hf}, \mathrm{La} / \mathrm{Th}, \mathrm{La} / \mathrm{Sc}$ ) indican que el ambiente tectónico del área fuente pudo ser un arco de islas continental y/o 
un margen activo continental. La signatura geoquímica de las metapsamitas de bajo grado (que incluye altos contenidos de Hfy Zr y valores altos de $\mathrm{Zr} / \mathrm{Sc}$ ), indica la presencia de una componente sedimentaria de reciclado cortical en estas rocas.

La geometría y secuencia de estructuras y microestructuras preservadas en la totalidad de las muestras estudiadas, sugieren que estas rocas comparten una historia de deformación común y uniforme durante la orogenia Pampeana. Tanto las signaturas geoquímicas como las estructuras de las rocas estudiadas indican que los protolitos sedimentarios de la Formacion Puncoviscana y rocas asociadas se depositaron en una cuenca relacionada con un arco volcánico que, subsecuentemente, fue deformada durante la orogenia Pampeana.

Palabras Clave: Geoquímica, rocas metasedimentarias, proveniencia, orogenia Pampeana, Formación Puncoviscana.

\section{Introduction}

The Ediacaran-Early Cambrian Puncoviscana Formation (Turner, 1960; Figure 1a), a thick turbiditic sequence exposed in the Puna and Cordillera Oriental and a series of metaclastic successions in Eastern Sierras Pampeanas, considered as its higher-grade equivalents (Willner and Miller, 1985; Rapela et al., 1998; Schwartz and Gromet, 2004), were initially deposited on the western margin of Gondwana during the Neoproterozoic to lower Cambrian and deformed and metamorphosed during the lower Cambrian Pampean orogeny (Rapela et al., 2002; Siegesmund et al., 2010; Escayola et al., 2011). The study of the geological evolution of the Puncoviscana Fm. and related rocks is critical to understand the Pampean orogeny and the early geodynamic evolution of the western Gondwana margin. We investigate the geochemical signature of these rocks in order to constrain their provenance and depositional tectonic setting, and to discuss their evolution during the Neoproterozoic-early Paleozoic. Previous provenance studies have been carried out in the region resulting in different interpretations and tectonic models (Do Campo and Ribeiro-Guevara, 2002, 2005; Zimmermann, 2005; Rapela et al., 2007; Collo et al., 2009; Drobe et al., 2011; Hauser et al., 2011). Thus, the depositional setting and tectonic evolution of the Puncoviscana metasedimentary rocks and related rocks during the lower Paleozoic is still under debate.

Geochemistry has been traditionally used to determine the provenance of clastic and metaclastic rocks and to constrain the tectonic setting in which they were deposited (e.g. McLennan et al., 1983, 1990, 1993, 1995; Taylor and McLennan, 1985, 1995; Bhatia and Crook, 1986; Roser and Korsch, 1985, 1988; Gu, 1996a, 1996b). Petrographic analyses based on framework modes are usually less useful than geochemical analyses in the characterization of provenance and tectonic setting of metamorphic rocks if the samples contain considerable amounts of pseudo matrix. The transformation of labile fragments originally present in the rock (i.e. feldspar or rock fragments) into clay minerals (pseudo matrix) can bias framework modes toward the quartz apices of classification diagrams (Do Campo and Ribeiro-Guevara, 2005). Furthermore, the geochemistry of metasediments is particularly valuable in the study of fine-grained rocks that are difficult to characterize through petrographic studies.

Major and trace elements can constraint the effects of weathering and sedimentary sorting, while rare earth and certain trace elements (e.g. Th, $\mathrm{Zr}, \mathrm{Hf}, \mathrm{Nb}$, and $\mathrm{Sc}$ ) are considered particularly reliable in the discrimination of provenance and tectonic setting. This reliability is based on their low mobility during sedimentary processes, diagenesis, and metamorphism, thus reflecting the signature of the parent materials, and the composition and tectonic environment of the source (Taylor and McLennan, 1985; McLennan, 1989; McLennan et al., 1993; Roser et al., 1996; Condie, 1991, 1993). Provenance studies of medium and high metamorphic grade metasediments are relatively common in the literature (i.e. Li et al., 2005; Meinhold et al., 2007; Drobe et al., 2011; Verdecchia and Baldo, 2010).

In this paper, we present new major and trace element whole-rock geochemical analyses from the Puncoviscana Fm. and related metasedimentary rocks from Cumbres Calchaquies, Sierras de Quilmes, Ancasti, and Córdoba (Figure 1). We combine our results with previously published data (Willner et al., 1985; Do Campo and RibeiroGuevara, 2005; Zimmermann, 2005) to evaluate their source and tectonic depositional setting. The characterization of the provenance and tectonic setting of these units is important for understanding the geodynamic evolution of the western Gondwana margin during the early Paleozoic. We also present new structural and microstructural data to support the correlation of our samples along the orogen during the Pampean cycle.

\section{Tectonic setting}

The Eastern Sierras Pampeanas are isolated basement blocks exhumed as a result of Tertiary to recent high-angle reverse faulting (Jordan and Allmendinger, 1986) associated with the flat slab subduction of the Nazca Plate (Ramos et al., 2002). These blocks include large outcrops of metaclastic rocks that extend between $26^{\circ}$ and $33^{\circ} \mathrm{S}$ (Figure 1), and were mainly affected by lower Cambrian deformation, metamorphism, and magmatism (the Pampean orogeny; e.g. Rapela et al., 1998, 2002; Siegesmund et al., 2010; Escayola et al., 2011). Based on isotope studies (e.g. Schwartz and Gromet, 2004; Steenken et al., 2004; Drobe et al., 2009 and 


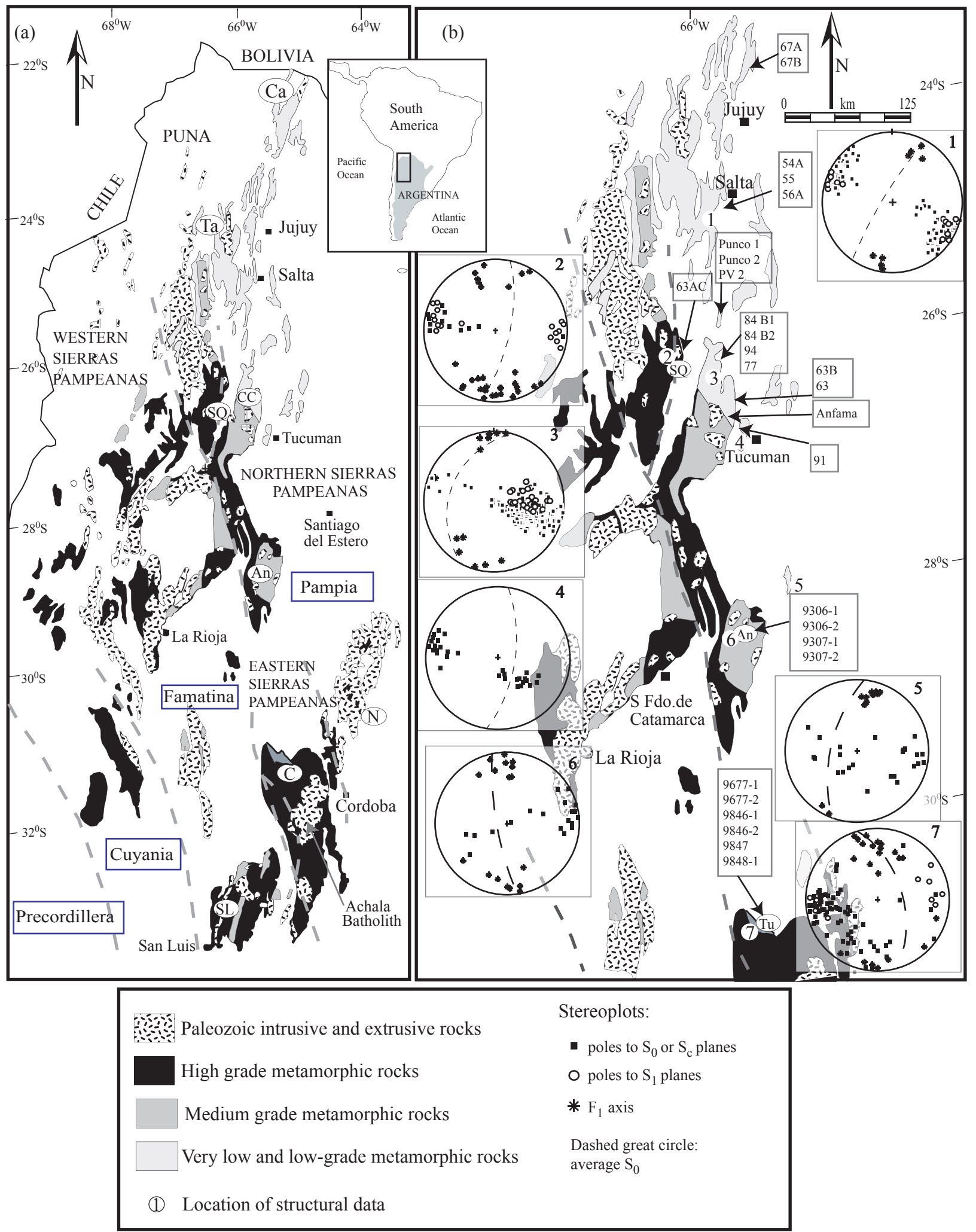

Figure 1. (a) Simplified geological map of lower Paleozoic rocks in NW Argentina, modified from Willner and Miller (1985), and Simpson et al. (2003). Inset shows the location of the research area in Argentina (boxed). Dashed lines indicate approximate boundaries between peri-Gondwanan terranes. (b) Puncoviscana Fm. and higher-grade related rocks with location of samples and structural data plotted on lower hemisphere stereographic projections. Number of structural data (stereoplot number here between parentheses): Salta (1) $\mathrm{S}_{0} \mathrm{n}=52, \mathrm{~S}_{1} \mathrm{n}=13 ; \mathrm{F}_{1}$ axes $n=8$; Quilmes (2) $\mathrm{S}_{0} \mathrm{n}=12, \mathrm{~S}_{1} \mathrm{n}=17, \mathrm{~F}_{1}$ axes $n=29$; Hualinchay (3) $S_{0} n=71, S_{1} n=22, F_{1}$ axes $n=12$; Sierra de San Javier (4) $S_{0} n=31$; Guasayan (5) $S_{0} n=25, F_{1}$ axes $n=12$; Ancasti (6) $S_{0} n=19$, $F_{1}$ axes $\mathrm{n}=17$; Tuclame (7) $\mathrm{S}_{0} \mathrm{n}=61, \mathrm{~S}_{1} \mathrm{n}=10, \mathrm{~F}_{1}$ axes $\mathrm{n}=21$.

Paleozoic mountain ranges and localities mentioned in the text: Tu. Tuclame; An. Ancasti; CC. Cumbres Calchaquies; C. Córdoba; SL. San Luis; N. Sierra del Norte; Ta. Sta. Rosa de Tástil; Ca. Cañaní; SQ Sierra de Quilmes. 
references therein) these rocks have been correlated with the Ediacaran to Early Cambrian Puncoviscana Formation (Turner, 1960) that crops out along a NNE-SSW linear belt that extends from the Bolivian border $\left(22^{\circ} \mathrm{S}\right)$ to the vicinity of Salta $\left(\sim 26^{\circ} \mathrm{S}\right.$; Figure 1a). Protoliths of the very low- to low-grade Puncoviscana Fm. and the medium- to high-grade metaclastic rocks of the Eastern Sierras Pampeanas have been interpreted by several authors as deposited in the same basin (Puncoviscana Basin) that extended from Bolivia to central Argentina $\left(\sim 33^{\circ} \mathrm{S}\right)$ roughly between $64^{\circ} \mathrm{W}$ and $68^{\circ} \mathrm{W}$ (Jezek, 1990; Rapela et al., 1990; Figure 1 of Zimmermann, 2005). However, the unexposed contact between low-grade and medium- to high-grade units, the discontinuity between outcrops, and the lack of a reliable stratigraphic column complicate the interpretation of the paleotectonism of the basin. Mon and Hongn (1991) subdivided the Pampean basement between $22^{\circ} \mathrm{S}$ to $28^{\circ} \mathrm{S}$ into several orogenic belts with a different tectonometamorphic evolution and suggest that higher-grade rocks are older than the Puncoviscana Fm.

The Puncoviscana Fm. includes successions of metamorphosed greywackes, siltstones, and mudstones, and locally interbedded metaconglomerates and discontinuous marble lenses (Jezek, 1990; Omarini et al., 1999; Porto et al., 1990); it also preserves sedimentary structures, and fossils of Ediacaran to Early Cambrian age (Aceñolaza and Durand, 1986; Durand, 1996). Sedimentological and facies analyses indicate a unidirectional pattern of sediment transport from east to west/northwest (presentday coordinates) from a common source area (Jezek et al., 1985; Jezek, 1990). Geochemical signatures of alkaline lava flows, sills, and basic dikes in the turbiditic section indicate oceanic-island to within-plate settings (Coira and Barber, 1987; Coira et al., 1990) consistent with a rift environment. Based on geochemical signatures obtained from basalts of uncertain stratigraphic position that are interbedded in metaclastic rocks of the Puncoviscana Fm., Omarini et al. (1999) suggest a transition from rift to a back-arc environment.

Idiomorphic detrital zircons from volcaniclastic beds in mid and upper stratigraphic levels of the Puncoviscana Fm. yielded an age range of 530-560 Ma (U-Pb, Lork et al., 1990), considered as a maximum sedimentation age. Adams et al., 2008a, 2008b reported maximum sedimentation ages of $636 \pm 7-551 \pm 5 \mathrm{Ma}$. More recently, Escayola et al. (2011) obtained ages of $536.4 \pm 5.3 \mathrm{Ma}$ and $537 \pm$ $0.9 \mathrm{Ma}$ from tuffaceous beds interlayered with metaclastic rocks of the Puncoviscana Fm. Detrital zircons from Puncoviscana Fm. rocks in the Cordillera Oriental yielded late Mesoproterozoic to early Neoproterozoic (850-1150 $\mathrm{Ma}$ ), and late Neoproterozoic-Early Cambrian (650-520 $\mathrm{Ma}) \mathrm{U}-\mathrm{Pb}$ age maxima (Adams et al., 2011). A similar age distribution of detrital zircon population was obtained by Escayola et al. (2011) and Hauser et al. (2011), but these authors describe much stronger late Ediacaran peaks suggesting that deposition of the Puncoviscana Fm. likely started in the latest Ediacaran but is mainly Early Cambrian, and was coeval with a nearby magmatic arc (Escayola et al., 2011). The depositional age of the Puncoviscana Fm. is additionally constrained by the unconformably overlying shallow marine platform metasedimentary rocks of the Meson Group that contain poorly preserved middle to Late Cambrian trilobites (Sánchez and Salfity, 1999; Aceñolaza et al., 2002; Aceñolaza and Aceñolaza 2005). Based on U-Pb geochronology of detrital zircons, and the pre-depositional Santa Rosa de Tastil batholith, Augustsson et al. (2011) suggest a mainly middle Cambrian depositional age for the Meson Group. Adams et al. (2011) report a youngest zircon component at $500 \mathrm{Ma}$, suggesting an upper age limit of Late Cambrian for the Meson Group.

Low greenschist-facies metaclastic rocks in the vicinity of Tucumán $\left(\sim 26^{\circ}\right.$ to $\left.27^{\circ} \mathrm{S}\right)$, upper greeschist to lower amphibolite-facies metaclastic rocks of the Ancasti Formation $\left(\sim 28^{\circ}\right.$ to $30^{\circ} \mathrm{S}$ Figure 1; Willner, 1983), and greenschist to upper amphibolite- and granulite-facies metaclastic rocks in Sierras de Cordoba $\left(\sim 31^{\circ} \mathrm{S}\right.$ to $33^{\circ} \mathrm{S}$, Figure 1), all included in the morphostructural province of Sierras Pampeanas (Ramos, 1999), have been considered as deep structural levels of the Puncoviscana Fm. (Willner and Miller, 1985; Toselli, 1990; Willner, 1990; Rapela et al., 1998; Steenken et al., 2004; Siegesmund et al., 2010; Steenken et al., 2011). Late Neoproterozoic (570-680 Ma) and Mesoproterozoic (960-1020 Ma) detrital zircon age maxima have been obtained from banded schists of the Ancasti Formation (U-Pb; Rapela et al., 2007). Similarly, Neoproterozoic (600-700 Ma) and Mesoproterozoic (900-1000 Ma) detrital zircon age maxima characterize metasedimentary rocks from the Sierras de Córdoba (Rapela et al., 1998; Schwartz and Gromet, 2004; Escayola et al., 2007; Drobe et al., 2009).

$\mathrm{Sr}$ and $\mathrm{Nd}$-isotope data from Puncoviscana Fm. and higher-grade related rocks are relatively homogeneous, suggesting that most NW Argentinian basement rocks shared similar sources (Becchio et al., 1999; Lucassen et al., 2000). Nd-model $\left(\mathrm{T}_{\mathrm{DM}}\right)$ ages from the low-grade Puncoviscana Formation range from 1600 to $1800 \mathrm{Ma}$ (Bock et al., 2000; Drobe et al., 2009), and from 1700 to $1800 \mathrm{Ma}$ in Sierras de Córdoba metasedimentary rocks (Rapela et al., 1998; Steenken et al., 2011; Drobe et al., 2011). Similar T model ages (average $\mathrm{T}_{\mathrm{DM}}$ age $\sim 1.76 \pm 0.4 \mathrm{Ga}$ ) were reported from Sierra de Quilmes metasedimentary rocks (Figure 1; Lucassen et al., 2000).

In Sierras de Córdoba, a main migmatization event occurred at $\sim 530 \mathrm{Ma}$ (U/Pb SHRIMP zircon ages; Rapela et al., 1998, 2002). Although its significance is still not very well constrained and further geochronological work may be necessary, an earlier $543 \pm 3.6 \mathrm{Ma}$ (U/Pb zircon age) metamorphic event has been proposed by Siegesmund et al. (2010) for high-grade non-migmatitic gneisses of Sierras de Córdoba (Sierra Grande). Similarly, a first Pampean metamorphic event has been dated as 540-570 Ma (Rb/Sr whole rock data; Bachmann and Grauert, 1986; Bachmann et al., 1987) in banded schists of the Ancasti Formation. 
The $523.7 \pm 0.8$ Ma calc-alkaline Cañaní pluton (U$\mathrm{Pb}$ TIMS zircon age, Escayola et al., 2011), and the 536 $\pm 7 \mathrm{Ma}$ or $534 \pm 7 \mathrm{Ma}$ Santa Rosa de Tástil calc-alkaline granite (Figure 1a; U-Pb zircon ages of Bachmann et al., 1987, and U-Pb Laser ICPMS zircon ages of Hauser et al., 2011, respectively) were emplaced in the chevron-folded Puncoviscana Fm. and are interpreted as part of a 'Pampean' magmatic arc (Omarini et al., 1999). In Sierras de Córdoba, the $530 \pm 3$ Ma calc-alkaline Sierra del Norte batolith (U$\mathrm{Pb}$ zircon ages, Rapela et al., 1998) is considered to be the southward extension of the Pampean magmatic arc (Lira et al., 1997). Based on U-Pb zircon ages, Schwartz et al. (2008) suggested that the activity of this arc extended from ca. 555 to $525 \mathrm{Ma}$. The $522 \pm 8 \mathrm{Ma}$ (U-Pb monazite ages, Rapela et al., 1998) and 515-520 Ma (U-Pb monazite ages, Gromet and Simpson, 1999, 2000) peraluminous granites and migmatites in Sierras de Córdoba contain xenoliths of folded metasediments, suggesting that shortening of these rocks occurred prior to migmatization (Piñán-Llamas and Simpson, 2006). K/Ar and Ar/Ar muscovite ages starting at $502 \mathrm{Ma}$ (Krol and Simpson, 1999; Steenken et al., 2010) and 505.7 \pm 7.3 Ma ages (PbSL titanite age; Siegesmund et al., 2010) likely indicate the end of the Pampean metamorphism in the Córdoba region (Siegesmund et al., 2010; Steenken et al., 2011).

A number of collisional and non-collisional models have been proposed to explain the Pampean orogeny. In noncollisional models, the Puncoviscana turbiditic sediments were initially passive margin deposits (e.g. Durand, 1996) that likely evolved into an accretionary prism due to eastward subduction in the lower Cambrian (Rapela et al., 1998; Omarini et al., 1999; Piñán-Llamas and Simpson, 2006). During this process, the Puncoviscana Fm. and higher-grade metasediments of the Sierras de Córdoba were intruded by the calc-alkaline 'Pampean' magmatic arc (or 'Tilcaric arc', Omarini et al., 1999) and the Sierra del Norte complex (Figure 1a; Lira et al., 1997; Schwartz et al., 2008), respectively. The Pampean cycle ended with an episode of peraluminous magmatism, related to subduction of a midocean ridge under the Puncoviscana accretionary prism as the arc magmatism was coming to a close (Fantini et al., 1998; Simpson et al., 2003; Schwartz et al., 2008). Schwartz et al. (2008) suggest that east-dipping subduction at $c a$. $555 \mathrm{Ma}$ was likely followed by the ridge-trench collision at $525 \mathrm{Ma}$. In alternative models based on structural and geochronological data, the Puncoviscana sediments are foreland (Zimmermann, 2005; Ramos, 2008), fore-arc (e.g. Astini et al., 1996; Pankhurst et al., 1997), or backarc basin deposits (Omarini et al., 1999; Escayola et al., 2007; Collo et al., 2009) tectonized in the mid-Cambrian Pampean orogeny.

In collisional models, the Puncoviscana Fm. and highergrade related rocks were part of independent terranes (e.g. the 'Pampia terrane' of Ramos et al., 1986 and Ramos, 1988) that collided with the western Gondwana margin during the Pampean orogeny. In related models, the Pampean orogeny has been associated with the accretion of the allochtonous or para-autochtonous Pampia block (Rapela et al., 1998; Ramos, 2008; Collo et al., 2009) or the Western Sierras Pampeanas (Rapela et al., 2007; Siegesmund et al., 2009 and references therein) to the western margin of Gondwana. Consistent with collisional models is the presence of a discontinuous string of thin bodies of MORB-basalts in the Sierras de Córdoba that has been interpreted as a disrupted ophiolitic sequence (Escayola et al., 2007; Ramos et al., 2000; Rapela et al., 1998; Steenken et al., 2011).

Isotopic and geochronological affinities between the Puncoviscana Fm. and related metaclastic rocks to the south, and Gondwanan sources in South Africa, led some authors to propose an alternative model in which the Puncoviscana sediments were deposited in a trough marginal to the Kalahari craton and later emplaced against the western margin of the Rio de la Plata craton through a lateral strikeslip displacement (Rapela et al., 2007; Casquet et al., 2008; Drobe et al., 2009, 2011; Siegesmund et al., 2010). Based on Sm-Nd isotopic data and zircon provenance patterns, Collo et al. (2009) proposed that the Puncoviscana Fm. and equivalent protoliths within Sierras Pampeanas were deposited in a back-arc basin to the west of a Brasiliano magmatic arc that developed on a Mesoproterozoic basement extension of the Arequipa-Antofalla massif (Collo et al., 2009).

After the Pampean orogeny, the Pacific margin of Gondwana turned into a passive margin. Magmatism and tectonism were resumed in the Early Ordovician during the Famatinian Orogeny (Aceñolaza and Toselli, 1973). Ordovician magmatism, dated as $\sim 470 \mathrm{Ma}$ (Büttner et al., 2005; Dahlquist et al., 2012) locally affected the Puncoviscana Fm., and high-grade equivalents, resetting isotopic systems (e.g. Sierra de Ancasti, Sierra de Quilmes). According to several models, the Arequipa, Cuyania/ Precordillera, and Chilenia terranes were likely accreted to the Pacific margin of Gondwana (Ramos et al., 1986; Ramos, 1988; Bahlburg and Hervé, 1997; Thomas and Astini, 2003; Collo et al., 2009; Ramos, 2008, 2009; Steenken et al., 2011; Drobe et al., 2011) during the rest of the Paleozoic. Separation of the Pampean Orogen into isolated basement blocks with intervening pull-apart basins began in the late Carboniferous and continued through the Cretaceous. Exhumation of basement blocks on high-angle, Tertiary to Recent reverse faults has been related to the Andean orogeny (Jordan and Allmendinger, 1986).

\section{Methodology}

A total of 27 samples from the Puncoviscana Fm. (Cordillera Oriental) and higher-grade metaclastic sediments from Cumbres Calchaquies, Sierras de Ancasti, Quilmes, and Córdoba were collected for petrographic and geochemical analyses (approximate locations of the samples in Figure 1b; coordinates and description of the samples in 
Appendix I). The analyzed samples include metapelites, massive psammites, and banded metapsammites that are the main lithologies present in the sampled areas. All samples were crushed. Fifty-five $m$ ajor, trace, and rare earth elements were determined (Table 1) by Activation Laboratories Ltd. (Ontario, Canada) according to their Code 4Lithoresearch and Code 4B1 packages. These packages combine lithium metaborate/tetraborate fusion

Table 1. Whole-rock major, minor, and rare-earth element abundances for Puncoviscana Fm. and higher-grade related rocks. Upper continental crust values (UCC) from McLennan, 2001.

\begin{tabular}{|c|c|c|c|c|c|c|c|c|c|c|c|c|c|c|c|}
\hline SAMPLE & & PUNCO 1 & Punco 2 & $56 \mathrm{~A}$ & $67 \mathrm{~A}$ & 55 & $54 \mathrm{~A}$ & $67 \mathrm{~B}$ & PV2 & $63 \mathrm{~B}$ & 63 & 91 & ANFAMA & $84 \mathrm{~B} 2$ & 94 \\
\hline $\mathrm{SiO}_{2}$ & $\%$ & 75.49 & 68.86 & 75.84 & 75.07 & 61.54 & 50.52 & 58.11 & 53.85 & 75.05 & 75.56 & 77.55 & 81.44 & 79.12 & 73.71 \\
\hline $\mathrm{TiO}_{2}$ & $\%$ & 0.54 & 0.68 & 0.61 & 0.85 & 0.82 & 1.08 & 0.79 & 0.94 & 0.72 & 0.53 & 0.49 & 0.43 & 0.43 & 0.58 \\
\hline $\mathrm{Al}_{2} \mathrm{O}_{3}$ & $\%$ & 10.53 & 13.69 & 10.22 & 10.78 & 17.40 & 22.58 & 18.86 & 20.42 & 10.88 & 10.97 & 10.31 & 8.80 & 10.02 & 11.11 \\
\hline $\mathrm{Fe}_{2} \mathrm{O}_{3}$ tot & $\%$ & 3.35 & 4.84 & 3.41 & 4.87 & 6.94 & 8.49 & 8.18 & 8.68 & 3.89 & 2.64 & 2.77 & 2.67 & 3.39 & 3.96 \\
\hline $\mathrm{MnO}$ & $\%$ & 0.04 & 0.05 & 0.12 & 0.06 & 0.06 & 0.10 & 0.11 & 0.09 & 0.07 & 0.04 & 0.07 & 0.05 & 0.05 & 0.07 \\
\hline $\mathrm{MgO}$ & $\%$ & 1.08 & 1.37 & 0.66 & 1.58 & 2.91 & 3.69 & 3.4 & 3.65 & 1.56 & 1.19 & 1.09 & 1.05 & 1.48 & 2.12 \\
\hline $\mathrm{Na}_{2} \mathrm{O}$ & $\%$ & 2.49 & 2.85 & 2.67 & 2.29 & 2.08 & 1.41 & 1.1 & 2.02 & 2.95 & 2.82 & 2.15 & 2.5 & 1.83 & 3.1 \\
\hline $\mathrm{K}_{2} \mathrm{O}$ & $\%$ & 2.21 & 3.17 & 2.08 & 2 & 4.44 & 6.91 & 5.19 & 5.55 & 1.85 & 2.12 & 2.08 & 1.44 & 2.13 & 1.37 \\
\hline $\mathrm{P}_{2} \mathrm{O}_{5}$ & $\%$ & 0.18 & 0.21 & 0.2 & 0.21 & 0.17 & 0.21 & 0.16 & 0.2 & 0.21 & 0.2 & 0.18 & 0.16 & 0.12 & 0.18 \\
\hline LOI & $\%$ & 2.83 & 2.74 & 2.41 & 2.07 & 3.58 & 4.84 & 4.27 & 4.1 & 0.58 & 2.48 & 1 & 0.47 & 0.88 & 2.39 \\
\hline Total & $\%$ & 100.47 & 99.28 & 99.79 & 100.25 & 100.22 & 100.18 & 100.43 & 99.77 & 99.44 & 100.19 & 99.94 & 100.26 & 100.40 & 99.95 \\
\hline CIA & & 53.34 & 60.03 & 53.10 & 63.15 & 67.59 & 69.45 & 71.46 & 68.57 & 53.57 & 53.74 & 52.11 & 53.77 & 59.71 & 56.28 \\
\hline ICV & & 1.08 & 1.00 & 1.08 & 1.12 & 1.00 & 0.97 & 1.00 & 1.03 & 1.16 & 1.00 & 1.05 & 1.06 & 1.02 & 1.12 \\
\hline $\mathrm{Ba}$ & ppm & 178 & 247 & 320 & 232 & 340 & 479 & 575 & 624 & 357 & 296 & 287 & 205 & 229 & 210 \\
\hline $\mathrm{Sr}$ & ppm & 67 & 55 & 62 & 51 & 44 & 36 & 24 & 46 & 188 & 103 & 212 & 111 & 120 & 103 \\
\hline $\mathrm{V}$ & ppm & 58 & 82 & 61 & 89 & 113 & 164 & 130 & 154 & 68 & 54 & 49 & 39 & 48 & 62 \\
\hline $\mathrm{Cr}$ & ppm & 40 & 60 & 40 & 60 & 90 & 120 & 100 & 120 & 60 & 50 & 40 & 40 & 40 & 50 \\
\hline $\mathrm{Ni}$ & ppm & 20 & 30 & $<20$ & $<20$ & 30 & 40 & 40 & 40 & $<20$ & $<20$ & $<20$ & $<20$ & 20 & 30 \\
\hline Co & ppm & 8 & 13 & 8 & 10 & 20 & 23 & 23 & 26 & 9 & 8 & 7 & 6 & 9 & 14 \\
\hline $\mathrm{Cu}$ & ppm & $<10$ & $<10$ & 20 & 10 & 30 & 30 & 30 & 100 & $<10$ & $<10$ & 10 & 10 & 10 & 20 \\
\hline $\mathrm{Y}$ & ppm & 27.6 & 25.3 & 33.8 & 32 & 36.8 & 44.9 & 27.7 & 39 & 29.7 & 24.9 & 25.8 & 18.8 & 22.8 & 26.3 \\
\hline $\mathrm{Zr}$ & ppm & 365 & 173 & 581 & 534 & 178 & 223 & 147 & 176 & 330 & 236 & 247 & 243 & 138 & 179 \\
\hline Cs & ppm & 3.8 & 7 & 5.3 & 4.2 & 12.7 & 18.3 & 10.3 & 13.2 & 5.2 & 5.2 & 5.5 & 4.1 & 4.4 & 3.3 \\
\hline Hf & ppm & 9.9 & 4.6 & 15.2 & 13.5 & 4.7 & 6.2 & 4.2 & 4.9 & 8.5 & 6.3 & 6.8 & 6.3 & 3.7 & 4.8 \\
\hline $\mathrm{Nb}$ & ppm & 9.8 & 11.3 & 10.9 & 13 & 16.4 & 20.2 & 14.3 & 18 & 10.7 & 9.6 & 9.7 & 7.6 & 5.7 & 7.8 \\
\hline $\mathrm{Ta}$ & ppm & 1.04 & 1.17 & 1.06 & 1.22 & 1.49 & 1.9 & 1.42 & 1.61 & 1.05 & 0.93 & 0.95 & 0.71 & 0.6 & 0.75 \\
\hline $\mathrm{Pb}$ & ppm & 12 & 22 & 13 & 17 & 9 & 16 & 22 & 6 & 17 & 7 & 19 & 10 & 7 & 13 \\
\hline $\mathrm{Sc}$ & ppm & 8 & 11 & 8 & 10 & 17 & 23 & 19 & 22 & 9 & 8 & 7 & 6 & 6 & 9 \\
\hline $\mathrm{Zn}$ & ppm & 60 & 100 & 80 & 70 & 130 & 140 & 150 & 170 & 50 & 60 & 60 & 50 & 70 & 180 \\
\hline $\mathrm{Th}$ & ppm & 10.3 & 11.4 & 11 & 12.1 & 15.6 & 20.3 & 15.8 & 19.1 & 11.6 & 8.99 & 8.64 & 7.25 & 5.24 & 6.92 \\
\hline $\mathrm{U}$ & ppm & 2.64 & 2.44 & 3.01 & 2.87 & 3.63 & 4.87 & 3.25 & 6.93 & 2.55 & 2.03 & 1.89 & 1.7 & 1.57 & 1.93 \\
\hline Pr & ppm & 7.99 & 7.41 & 9.41 & 10.8 & 9.96 & 8.74 & 5.86 & 9.39 & 8.08 & 7.14 & 6.84 & 5.43 & 5.17 & 6.69 \\
\hline $\mathrm{Nd}$ & ppm & 29.9 & 27.3 & 35.2 & 40.9 & 38.4 & 33.7 & 21.8 & 36 & 31.4 & 27.7 & 25.4 & 21.2 & 20.8 & 26.5 \\
\hline $\mathrm{Sm}$ & ppm & 5.86 & 5.46 & 6.81 & 7.83 & 7.46 & 7.2 & 4.41 & 6.79 & 6.36 & 5.19 & 4.98 & 4.03 & 4.37 & 5.25 \\
\hline $\mathrm{Eu}$ & ppm & 1.17 & 1.08 & 1.28 & 1.47 & 1.43 & 1.56 & 0.996 & 1.12 & 1.31 & 1.13 & 1.08 & 0.874 & 1.12 & 1.15 \\
\hline $\mathrm{Gd}$ & ppm & 5.42 & 4.95 & 6.22 & 6.79 & 6.93 & 7.3 & 4.38 & 5.83 & 5.71 & 4.86 & 4.59 & 3.6 & 4.33 & 4.86 \\
\hline $\mathrm{Tb}$ & ppm & 0.88 & 0.84 & 1.02 & 1.1 & 1.13 & 1.4 & 0.83 & 0.95 & 0.95 & 0.75 & 0.76 & 0.57 & 0.75 & 0.8 \\
\hline Dy & ppm & 5.09 & 4.81 & 5.85 & 5.91 & 6.43 & 8.25 & 5.01 & 5.58 & 5.33 & 4.35 & 4.3 & 3.33 & 4.12 & 4.59 \\
\hline Ho & ppm & 0.98 & 0.92 & 1.12 & 1.1 & 1.23 & 1.59 & 0.99 & 1.24 & 1.04 & 0.82 & 0.83 & 0.65 & 0.8 & 0.89 \\
\hline $\mathrm{Er}$ & ppm & 2.97 & 2.74 & 3.37 & 3.31 & 3.61 & 4.79 & 3.02 & 4.03 & 3.18 & 2.46 & 2.45 & 1.97 & 2.32 & 2.64 \\
\hline $\mathrm{Tm}$ & ppm & 0.446 & 0.446 & 0.519 & 0.514 & 0.546 & 0.73 & 0.486 & 0.654 & 0.501 & 0.385 & 0.381 & 0.319 & 0.335 & 0.386 \\
\hline $\mathrm{Yb}$ & ppm & 2.94 & 2.81 & 3.41 & 3.35 & 3.51 & 4.74 & 3.21 & 4.26 & 3.25 & 2.55 & 2.5 & 2.15 & 2.12 & 2.44 \\
\hline $\mathrm{Lu}$ & ppm & 0.449 & 0.396 & 0.547 & 0.519 & 0.513 & 0.682 & 0.5 & 0.637 & 0.506 & 0.385 & 0.378 & 0.327 & 0.326 & 0.379 \\
\hline $\mathrm{Li}$ & ppm & 2 & 3 & 2 & 2 & 3 & 5 & 3 & 4 & 2 & 2 & 2 & 1 & 1 & 2 \\
\hline$\sum \mathrm{REE}$ & & 168.60 & 156.16 & 198.96 & 227.89 & 220.85 & 201.08 & 128.89 & 200.78 & 167.72 & 153.12 & 139.79 & 120.35 & 109.96 & 141.78 \\
\hline $\mathrm{Zr} / \mathrm{Sc}$ & & 45.63 & 15.73 & 72.63 & 53.40 & 10.47 & 9.70 & 7.74 & 8.00 & 36.67 & 29.50 & 35.29 & 40.50 & 23.00 & 19.89 \\
\hline $\mathrm{Th} / \mathrm{Sc}$ & & 1.29 & 1.04 & 1.38 & 1.21 & 0.92 & 0.88 & 0.83 & 0.87 & 1.29 & 1.12 & 1.23 & 1.21 & 0.87 & 0.77 \\
\hline $\mathrm{Nb} / \mathrm{Y}$ & & 0.36 & 0.45 & 0.32 & 0.41 & 0.45 & 0.45 & 0.52 & 0.46 & 0.36 & 0.39 & 0.38 & 0.40 & 0.25 & 0.30 \\
\hline $\mathrm{La} / \mathrm{Sc}$ & & 4.29 & 2.98 & 5.10 & 4.78 & 2.68 & 1.68 & 1.33 & 1.80 & 3.58 & 4.00 & 4.14 & 3.85 & 3.35 & 3.03 \\
\hline $\mathrm{La} / \mathrm{Th}$ & & 3.33 & 2.88 & 3.71 & 3.95 & 2.92 & 1.91 & 1.60 & 2.07 & 2.78 & 3.56 & 3.36 & 3.19 & 3.84 & 3.95 \\
\hline $\mathrm{Th} / \mathrm{U}$ & & 3.90 & 4.67 & 3.65 & 4.22 & 4.30 & 4.17 & 4.86 & 2.76 & 4.55 & 4.43 & 4.57 & 4.26 & 3.34 & 3.59 \\
\hline $\mathrm{Cr} / \mathrm{V}$ & & 0.69 & 0.73 & 0.66 & 0.67 & 0.80 & 0.73 & 0.77 & 0.78 & 0.88 & 0.93 & 0.82 & 1.03 & 0.83 & 0.81 \\
\hline $\mathrm{Cr} / \mathrm{Th}$ & & 3.88 & 5.26 & 3.64 & 4.96 & 5.77 & 5.91 & 6.33 & 6.28 & 5.17 & 5.56 & 4.63 & 5.52 & 7.63 & 7.23 \\
\hline $\mathrm{Eu} / \mathrm{Eu}^{*}$ & & 0.63 & 0.63 & 0.60 & 0.62 & 0.61 & 0.66 & 0.69 & 0.54 & 0.66 & 0.69 & 0.69 & 0.70 & 0.79 & 0.70 \\
\hline $\mathrm{Ce} / \mathrm{Ce}^{*}$ & & 0.99 & 0.96 & 1.00 & 1.00 & 1.03 & 1.04 & 1.00 & 1.03 & 0.99 & 0.98 & 0.94 & 1.10 & 1.00 & 1.00 \\
\hline$(\mathrm{La} / \mathrm{Yb}) \mathrm{n}$ & & 7.88 & 7.89 & 8.09 & 9.64 & 8.78 & 5.52 & 5.33 & 6.28 & 6.70 & 8.48 & 7.84 & 7.26 & 6.41 & 7.56 \\
\hline$(\mathrm{La} / \mathrm{Sm}) \mathrm{n}$ & & 3.68 & 3.78 & 3.77 & 3.84 & 3.85 & 3.38 & 3.61 & 3.67 & 3.19 & 3.88 & 3.67 & 3.61 & 2.90 & 3.27 \\
\hline$(\mathrm{Gd} / \mathrm{Yb}) \mathrm{n}$ & & 1.49 & 1.43 & 1.48 & 1.64 & 1.60 & 1.25 & 1.11 & 1.11 & 1.42 & 1.54 & 1.49 & 1.36 & 1.66 & 1.61 \\
\hline
\end{tabular}


Table 1. (Continuation).

\begin{tabular}{|c|c|c|c|c|c|c|c|c|c|c|c|c|c|c|c|}
\hline SAMPLE & & 77 & $84 \mathrm{~B} 1$ & $63 \mathrm{AC}$ & $9306-2$ & $9307-2$ & 9306-1 & $9307-1$ & $9846-2$ & $9677-2$ & 9847.000 & 9846-1 & $9677-1$ & 9848-1 & UCC \\
\hline $\mathrm{SiO}_{2}$ & $\%$ & 77.14 & 64.28 & 78.30 & 77.17 & 76.02 & 58.94 & 54.09 & 77.08 & 73.44 & 68.28 & 57.36 & 47.78 & 52.26 & 66.00 \\
\hline $\mathrm{TiO}_{2}$ & $\%$ & 0.68 & 0.77 & 0.59 & 0.48 & 0.52 & 0.96 & 1.14 & 0.48 & 0.54 & 0.90 & 0.94 & 1.30 & 1.10 & 0.50 \\
\hline $\mathrm{Al}_{2} \mathrm{O}_{3}$ & $\%$ & 10.45 & 17.99 & 9.91 & 10.92 & 11.37 & 19.09 & 21.29 & 10.82 & 11.58 & 15.24 & 20.84 & 22.31 & 22.66 & 15.20 \\
\hline $\mathrm{Fe}_{2} \mathrm{O}_{3}$ tot & $\%$ & 3.98 & 5.20 & 3.51 & 3.72 & 4.24 & 6.87 & 7.68 & 3.65 & 4.20 & 6.37 & 6.26 & 10.94 & 8.49 & 4.50 \\
\hline $\mathrm{MnO}$ & $\%$ & 0.05 & 0.08 & 0.08 & 0.05 & 0.06 & 0.08 & 0.12 & 0.06 & 0.06 & 0.12 & 0.10 & 0.15 & 0.11 & 0.08 \\
\hline $\mathrm{MgO}$ & $\%$ & 1.82 & 2.21 & 1.45 & 1.78 & 1.74 & 3.29 & 3.05 & 1.62 & 1.84 & 2.53 & 2.73 & 4.81 & 4.24 & 2.20 \\
\hline $\mathrm{CaO}$ & $\%$ & 0.38 & 0.9 & 1.64 & 0.87 & 0.33 & 1.34 & 0.55 & 0.92 & 1.24 & 1.00 & 1.51 & 1.95 & 1.53 & 4.20 \\
\hline $\mathrm{Na}_{2} \mathrm{O}$ & $\%$ & 2.85 & 1.77 & 2.37 & 1.51 & 2.15 & 2.38 & 2.68 & 1.76 & 2.17 & 1.20 & 2.78 & 3.45 & 1.92 & 3.90 \\
\hline $\mathrm{K}_{2} \mathrm{O}$ & $\%$ & 1.38 & 4.85 & 1.62 & 2.25 & 2.41 & 4.56 & 5.61 & 2.46 & 2.32 & 3.88 & 4.96 & 5.29 & 5.15 & 3.40 \\
\hline $\mathrm{P}_{2} \mathrm{O}_{5}$ & $\%$ & 0.2 & 0.16 & 0.18 & 0.13 & 0.17 & 0.15 & 0.26 & 0.13 & 0.22 & 0.14 & 0.20 & 0.29 & 0.29 & 0.17 \\
\hline LOI & $\%$ & 1.65 & 1.98 & 0.64 & 1.47 & 1.55 & 2.51 & 2.89 & 0.89 & 0.88 & & 2.11 & 1.56 & 2.67 & \\
\hline Total & $\%$ & 100.58 & 100.18 & 100.29 & 100.35 & 100.56 & 100.16 & 99.36 & 99.86 & 98.49 & 99.65 & 99.80 & 99.83 & 100.42 & 100.15 \\
\hline CIA & & 62.02 & 65.61 & 54.69 & 63.80 & 64.18 & 63.57 & 66.19 & 60.97 & 59.70 & 66.52 & 63.03 & 60.99 & 67.65 & \\
\hline ICV & & 1.06 & 0.87 & 1.13 & 0.97 & 1.00 & 1.02 & 0.97 & 1.01 & 1.06 & 0.98 & 0.92 & 1.24 & 0.99 & \\
\hline $\mathrm{Ba}$ & ppm & 258 & 662 & 243 & 297 & 261 & 570 & 615 & 289 & 303 & 615.68 & 694 & 551 & 779 & 550 \\
\hline $\mathrm{Rb}$ & $\mathrm{ppm}$ & 58 & 160 & 73 & 95 & 96 & 205 & 222 & 93 & 96 & 132.46 & 174 & 242 & 225 & 112 \\
\hline $\mathrm{Sr}$ & $\mathrm{ppm}$ & 73 & 116 & 130 & 98 & 53 & 162 & 96 & 114 & 116 & 81.28 & 187 & 201 & 120 & 350 \\
\hline $\mathrm{V}$ & $\mathrm{ppm}$ & 61 & 100 & 59 & 82 & 63 & 151 & 141 & 53 & 74 & & 119 & 156 & 151 & 107 \\
\hline $\mathrm{Cr}$ & $\mathrm{ppm}$ & 50 & 80 & 50 & 50 & 50 & 110 & 120 & 40 & 50 & 81.78 & 90 & 160 & 140 & 83 \\
\hline $\mathrm{Ni}$ & $\mathrm{ppm}$ & $<20$ & 20 & $<20$ & $<20$ & $<20$ & 40 & 40 & $<20$ & 30 & & 30 & 60 & 50 & 44 \\
\hline Co & $\mathrm{ppm}$ & 11 & 15 & 8 & 12 & 11 & 25 & 21 & 10 & 12 & 23.11 & 17 & 32 & 24 & 17 \\
\hline $\mathrm{Cu}$ & $\mathrm{ppm}$ & 20 & 10 & 10 & 20 & 20 & 20 & 20 & $<10$ & 10 & 6.47 & $<10$ & 30 & 30 & 25 \\
\hline $\mathrm{Y}$ & $\mathrm{ppm}$ & 32.4 & 40.5 & 31.5 & 22 & 26.6 & 37.3 & 41.7 & 24.2 & 22.2 & 28.50 & 44 & 48.1 & 48.7 & 22 \\
\hline $\mathrm{Zr}$ & $\mathrm{ppm}$ & 317 & 255 & 283 & 132 & 157 & 169 & 262 & 149 & 144 & 132.26 & 269 & 201 & 225 & 190 \\
\hline $\mathrm{Cs}$ & $\mathrm{ppm}$ & 3.6 & 7.5 & 5.7 & 6.9 & 5.9 & 13.5 & 11.4 & 5.3 & 6.2 & 7.26 & 8.3 & 16.8 & 12.4 & 4.6 \\
\hline $\mathrm{Hf}$ & $\mathrm{ppm}$ & 8.2 & 6.7 & 7.7 & 3.6 & 4.4 & 4.5 & 7.3 & 4 & 3.8 & 3.83 & 7.1 & 6 & 6.6 & 5.8 \\
\hline $\mathrm{Nb}$ & $\mathrm{ppm}$ & 10.4 & 13.8 & 7.9 & 7.5 & 10.3 & 14.9 & 19.9 & 6.6 & 7.5 & 13.04 & 12.7 & 18.3 & 18.1 & 12 \\
\hline $\mathrm{Ta}$ & $\mathrm{ppm}$ & 1 & 4.08 & 0.77 & 0.73 & 1.03 & 1.32 & 1.92 & 0.6 & 0.74 & 0.86 & 1.18 & 1.93 & 1.75 & 1 \\
\hline $\mathrm{Pb}$ & $\mathrm{ppm}$ & 8 & 9 & 54 & 21 & 12 & 32 & 17 & 6 & 23 & 30.00 & 10 & 40 & 28 & 17 \\
\hline $\mathrm{Sc}$ & $\mathrm{ppm}$ & 8 & 14 & 8 & 9 & 9 & 17 & 20 & 7 & 10 & 15.76 & 16 & 25 & 21 & 13.6 \\
\hline $\mathrm{Zn}$ & $\mathrm{ppm}$ & 60 & 110 & 140 & 90 & 90 & 160 & 150 & 50 & 80 & 129.09 & 100 & 180 & 190 & 71 \\
\hline Th & $\mathrm{ppm}$ & 10.2 & 10.2 & 8.6 & 6.22 & 9.02 & 11.7 & 21.4 & 6.03 & 6.86 & 6.95 & 12.1 & 19.2 & 16.2 & 10.7 \\
\hline $\mathrm{U}$ & $\mathrm{ppm}$ & 2.53 & 2.98 & 2.4 & 1.53 & 1.92 & 2.7 & 3.06 & 1.82 & 2.22 & 2.12 & 3.61 & 4.85 & 4 & 2.8 \\
\hline $\mathrm{La}$ & $\mathrm{ppm}$ & 35.8 & 35.5 & 31 & 21.3 & 38.3 & 35.2 & 47.2 & 21.2 & 24 & 24.60 & 42 & 63.3 & 52.3 & 30 \\
\hline $\mathrm{Ce}$ & $\mathrm{ppm}$ & 69.7 & 75.4 & 66.5 & 44.9 & 79.1 & 72.4 & 96.9 & 46.2 & 51 & 51.16 & 88 & 130 & 106 & 64 \\
\hline $\operatorname{Pr}$ & $\mathrm{ppm}$ & 8.74 & 8.75 & 7.74 & 5.15 & 8.63 & 8.23 & 11.2 & 5.28 & 5.91 & 6.25 & 10.3 & 14.3 & 12.3 & 7.1 \\
\hline $\mathrm{Nd}$ & $\mathrm{ppm}$ & 35.6 & 35.1 & 30.7 & 21 & 32.7 & 32.8 & 42.3 & 21.6 & 23.6 & 25.50 & 41.4 & 56.9 & 47.1 & 26 \\
\hline $\mathrm{Sm}$ & $\mathrm{ppm}$ & 7.07 & 7.56 & 6.33 & 4.42 & 6.23 & 6.78 & 8.96 & 4.53 & 5.01 & 5.56 & 8.79 & 10.6 & 9.38 & 4.5 \\
\hline $\mathrm{Eu}$ & $\mathrm{ppm}$ & 1.46 & 1.63 & 1.33 & 1.03 & 1.23 & 1.54 & 1.68 & 1.15 & 1.13 & 1.03 & 1.92 & 2.6 & 1.91 & 0.88 \\
\hline $\mathrm{Gd}$ & $\mathrm{ppm}$ & 6.78 & 7.15 & 6.17 & 4.12 & 5.63 & 6.76 & 8.18 & 4.41 & 4.94 & 5.13 & 8.52 & 10 & 8.69 & 3.8 \\
\hline $\mathrm{Tb}$ & $\mathrm{ppm}$ & 1.05 & 1.21 & 1 & 0.67 & 0.91 & 1.12 & 1.39 & 0.74 & 0.78 & 0.76 & 1.42 & 1.58 & 1.47 & 0.64 \\
\hline Dy & $\mathrm{ppm}$ & 5.92 & 6.89 & 5.79 & 3.82 & 4.92 & 6.45 & 7.79 & 4.38 & 4.37 & 4.93 & 7.94 & 9.22 & 8.2 & 3.5 \\
\hline Но & $\mathrm{ppm}$ & 1.11 & 1.34 & 1.09 & 0.74 & 0.9 & 1.2 & 1.48 & 0.84 & 0.82 & 0.97 & 1.49 & 1.77 & 1.55 & 0.8 \\
\hline $\mathrm{Er}$ & $\mathrm{ppm}$ & 3.28 & 4.02 & 3.17 & 2.16 & 2.68 & 3.45 & 4.39 & 2.53 & 2.36 & 2.91 & 4.41 & 5.23 & 4.57 & 2.3 \\
\hline $\mathrm{Tm}$ & $\mathrm{ppm}$ & 0.493 & 0.586 & 0.47 & 0.32 & 0.41 & 0.52 & 0.66 & 0.38 & 0.35 & 0.41 & 0.68 & 0.79 & 0.70 & 0.33 \\
\hline $\mathrm{Yb}$ & ppm & 3.2 & 3.72 & 3.07 & 2.08 & 2.6 & 3.4 & 4.2 & 2.46 & 2.26 & 2.73 & 4.38 & 5.02 & 4.44 & 2.2 \\
\hline $\mathrm{Lu}$ & $\mathrm{ppm}$ & 0.475 & 0.568 & 0.463 & 0.325 & 0.378 & 0.518 & 0.658 & 0.373 & 0.327 & 0.40 & 0.631 & 0.769 & 0.663 & 0.32 \\
\hline $\mathrm{Li}$ & $\mathrm{ppm}$ & 2 & 1 & 2 & 2 & 2 & 4 & 4 & 1 & $<1$ & & 2 & 2 & 6 & \\
\hline$\sum$ REE & & 180.68 & 189.42 & 164.83 & 112.04 & 184.62 & 180.37 & 236.99 & 116.07 & 126.86 & 132.34 & 221.88 & 312.08 & 259.27 & 146.37 \\
\hline $\mathrm{Zr} / \mathrm{Sc}$ & & 39.63 & 18.21 & 35.38 & 14.67 & 17.44 & 9.94 & 13.10 & 21.29 & 14.40 & 8.39 & 16.81 & 8.04 & 10.71 & 13.97 \\
\hline $\mathrm{Th} / \mathrm{Sc}$ & & 1.28 & 0.73 & 1.08 & 0.69 & 1.00 & 0.69 & 1.07 & 0.86 & 0.69 & 0.44 & 0.76 & 0.77 & 0.77 & 0.79 \\
\hline $\mathrm{Nb} / \mathrm{Y}$ & & 0.32 & 0.34 & 0.25 & 0.34 & 0.39 & 0.40 & 0.48 & 0.27 & 0.34 & 0.46 & 0.29 & 0.38 & 0.37 & 0.55 \\
\hline $\mathrm{La} / \mathrm{Sc}$ & & 4.48 & 2.54 & 3.88 & 2.37 & 4.26 & 2.07 & 2.36 & 3.03 & 2.40 & 1.56 & 2.63 & 2.53 & 2.49 & 2.21 \\
\hline $\mathrm{La} / \mathrm{Th}$ & & 3.51 & 3.48 & 3.60 & 3.42 & 4.25 & 3.01 & 2.21 & 3.52 & 3.50 & 3.54 & 3.47 & 3.30 & 3.23 & 2.80 \\
\hline $\mathrm{Th} / \mathrm{U}$ & & 4.03 & 3.42 & 3.58 & 4.07 & 4.70 & 4.33 & 6.99 & 3.31 & 3.09 & 3.28 & 3.35 & 3.96 & 4.05 & 3.82 \\
\hline $\mathrm{Cr} / \mathrm{V}$ & & 0.82 & 0.80 & 0.85 & 0.61 & 0.79 & 0.73 & 0.85 & 0.75 & 0.68 & & 0.76 & 1.03 & 0.93 & 0.78 \\
\hline $\mathrm{Cr} / \mathrm{Th}$ & & 4.90 & 7.84 & 5.81 & 8.04 & 5.54 & 9.40 & 5.61 & 6.63 & 7.29 & 11.76 & 7.44 & 8.33 & 8.64 & 7.76 \\
\hline $\mathrm{Eu} / \mathrm{Eu}^{*}$ & & 0.64 & 0.68 & 0.65 & 0.74 & 0.63 & 0.70 & 0.60 & 0.79 & 0.69 & 0.59 & 0.68 & 0.77 & 0.65 & 0.65 \\
\hline $\mathrm{Ce} / \mathrm{Ce}^{*}$ & & 0.92 & 1.00 & 1.01 & 1.00 & 1.02 & 1.00 & 0.99 & 1.02 & 1.00 & 0.97 & 0.99 & 1.01 & 0.98 & 1.07 \\
\hline$(\mathrm{La} / \mathrm{Yb}) \mathrm{n}$ & & 7.56 & 6.45 & 6.82 & 6.92 & 9.95 & 7.00 & 7.59 & 5.82 & 7.18 & 6.10 & 6.48 & 8.52 & 7.96 & 9.21 \\
\hline$(\mathrm{La} / \mathrm{Sm}) \mathrm{n}$ & & 3.19 & 2.96 & 3.08 & 3.03 & 3.87 & 3.27 & 3.32 & 2.95 & 3.02 & 2.79 & 3.01 & 3.76 & 3.51 & 4.20 \\
\hline$(\mathrm{Gd} / \mathrm{Yb}) \mathrm{n}$ & & 1.72 & 1.56 & 1.63 & 1.61 & 1.75 & 1.61 & 1.58 & 1.45 & 1.77 & 1.53 & 1.58 & 1.61 & 1.59 & 1.40 \\
\hline
\end{tabular}

ICP analysis for major elements with ICP-MS analysis for trace elements, using international rock standards (Activation Laboratories Ltd. 2006). According to replicates and standard results, the analytical precision was typically better than $\pm 2.3 \%$ for most major elements and better than $\pm 10 \%$ for trace elements. In the discussion we also include previously published compositions of metaclastic rocks from Sierra de Ancasti, and the Puncoviscana Fm. (data 
from Do Campo and Ribeiro-Guevara, 2005; Willner et al., 1985; and Zimmermann, 2005). In the following sections we summarize lithological, structural, petrographic, and microstructural observations from the analyzed samples and their outcrops.

\section{Sample Description}

\subsection{Puncoviscana Formation-Anchizone grade}

The Puncoviscana Fm. consists of anchizone-grade centimeter- to meter-thick massive metapsammitic beds alternating with centimeter-thick green and red metapelitic layers, and centimeter- to meter-thick layers of banded metapsammites. Massive metapsammitic layers containing graded- and cross-bedding and parallel lamination gradually transition into metapelitic layers. Three massive metapsammites (Punco 1, Punco 2, 56A), a banded metapsammite (67A), and four metapelitic samples $(55,54 \mathrm{~A}, 67 \mathrm{~B}, \mathrm{PV} 2)$ were collected for analysis (locations in Appendix I). In thin section, massive metapsammites and quartz-rich bands in banded metapsammitic samples are characterized by subangular, poorly sorted clasts of quartz, feldspar (mostly albite and minor K-feldspar), and rock fragments (quartzite, siltstone, shales, phyllites), clays, small detrital white micas, and few chlorite grains. Zircon, rutile, magnetite, and tourmaline are also present. In metapelitic rocks, elongated quartz grains with curved grain boundaries and pressure shadows are present. A compactionrelated, bedding-parallel cleavage $\left(\mathrm{S}_{\mathrm{c}}\right)$ is defined by aligned detrital micas, pressure-solution seams, and micabeards in banded and massive metapsammites, and metapelitic samples. Although Tertiary (Andean) deformation locally overprints older tectonic structures, predominant Pampean structures consist of N-S metric to decimetric chevron folds with mostly subhorizontal axes (Figure 1b) and subvertical axial planes that fold bedding and $\mathrm{S}_{\mathrm{c}}$. An $\mathrm{S}_{1}$ fanning cleavage associated with chevron folds intersects bedding and $S_{c}$, and is observed mostly in metapelitic rocks (Piñán-Llamas and Simpson, 2006, 2009).

4.2. Metaclastic rocks from Cumbres Calchaquies $\left(26^{\circ} \mathrm{S}\right.$ $27^{\circ} \mathrm{S}$ )- Low-Greenschist facies

Low greenschist-facies metaclastic sequences in northern Cumbres Calchaquies (Fm Medina, Gonzalez et al., 2000) include centimeter- to meter-thick levels of banded metapsammites, centimeter- to meter-thick massive metapsammitic beds, and centimeter-thick metapelitic beds. Cross- and graded-bedding, parallel lamination, slumps, and flame structures are preserved in metapsammites. Seven banded metapsammitic samples $(63 \mathrm{~B}, 63,91$, Anfama, 84B2, 94, 77) and one metapelitic sample (84B1) were analyzed for geochemistry (Figure 1b; Appendix I). Similarly to anchizone-grade samples, quartz-rich bands in banded metapsammitic samples are petrographically characterized by subangular quartz, feldspar (mostly albite), and rock fragments (quartzite, siltstone, shales). Local matrix recrystallization is observed. In both massive and banded metapsammitic samples, fine-grained detrital micas are preserved, but metamorphic white mica (illite; Toselli and Rossi de Toselli, 1983a, 1983b) and chlorite grains are more abundant than in lower-grade samples. Zircon, apatite, rutile, ilmenite, and tourmaline are common accessory minerals in metapsammitic samples. In thin section, a bedding-parallel cleavage $\left(\mathrm{S}_{\mathrm{c}}\right)$ is defined in metapelitic and metapsammitic samples by preferentially oriented detrital and metamorphic white micas and chlorite, elongated quartz grains with partially dissolved borders, and pressure-solution seams. A tectonic cleavage $\left(\mathrm{S}_{1}\right)$ associated with NNE-SSW metric to decimetric chevron folds is present in metapelitic and metapsammitic rocks. These folds, are characterized by subhorizontal axes (Figure 1b) and subvertical axial planes. In thin section, $\mathrm{S}_{1}$ is defined by asymmetric quartz grains with dissolved borders and pressure shadows, pressuresolution seams, preferentially aligned metamorphic white micas, and chlorite grains. At outcrop scale, $\mathrm{S}_{1}$ is observed as a fanning cleavage overprinting bedding and $\mathrm{S}_{\mathrm{c}}$ (PiñánLlamas and Simpson, 2006, 2009).

\subsection{NE Sierra de Quilmes}

In northeastern Sierra de Quilmes, the Tolombon Complex (Toselli et al., 1978) includes centimeter- to meter-thick banded metapsammitic levels, and centimeterscale metapelitic layers. Relict bedding surfaces and cross bedding are preserved. Banded metapsammites are defined by $2-10 \mathrm{~mm}$-thick quartz-rich domains alternating with 0.25-2.5 mm-thick biotite-rich domains. This compositional banding is subparallel to relict bedding. A quartz-rich banded metapsammitic sample (63AC) was collected for geochemical analysis (Figure 1b). In thin section, banded metapsammites are characterized by quartz-rich domains of recrystallized quartz with few interspersed plagioclase and biotite grains; biotite-rich bands are predominantly formed by large corroded and kinked biotite grains with quartz and opaque inclusions. Zircon, apatite, ilmenite, and tourmaline are accessory minerals in these rocks. Relict bedding and compositional banding are folded by NNE-SSW trending metric to decametric-scale chevron folds (Figure 1b) and $\mathrm{cm}$-scale parasitic folds $\left(\mathrm{F}_{1}\right)$ with subvertical axial planes and subhorizontal axis. Cleavage associated with these folds $\left(\mathrm{S}_{1}\right)$ crosscuts the relict bedding and compositional banding. $\mathrm{S}_{1}$ is defined by preferentially aligned large idiomorphic metamorphic biotite grains and, locally, by small white micas.

\subsection{Ancasti Formation}

The Ancasti Formation (Figure 1) includes metric to cmthick metapelitic levels with interlayered psammitic lenses, 
massive metapsammitic levels, and banded metapsammites (Willner and Miller, 1982; Willner, 1983). The compositional banding is subparallel to bedding relicts. Two samples of banded metapsammites (9306-2, 9307-2) and two samples of metapelites (9306-1, 9307-1) were geochemically analyzed (location and description of the samples in Appendix I). Banded metapsammites are characterized by alternating thin biotite-rich and thicker granoblastic quartz-rich layers that include small interspersed biotite grains and plagioclase (mostly albite). NNW to N-S trending upright $\mathrm{cm}$-scale $\mathrm{F}_{1}$ folds with an associated axial plane cleavage $\left(\mathrm{S}_{1}\right)$ affect bedding relicts and compositional banding. Preferentially oriented idiomorphic biotite grains define $\mathrm{S}_{1}$.

\subsection{Tuclame Formation}

Centimeter- to meter-thick layers of metapelites and meter- to several meters-thick banded metapsammites occur along the westernmost edge of the Sierras de Córdoba (the Tuclame Formation, Figure 1). Banded metapsammites are characterized by a monotonous compositional banding, which is subparallel to bedding relicts, defined by $\mathrm{cm}$-thick quartz-rich bands alternating with $2-5$-mm thick biotiterich layers. A very similar compositional banding occurs in lower-grade rocks of the Puncoviscana Fm., where primary structures are well preserved. Three samples of banded psammites (9846-2, 9677-2, 9847) and three metapelitic samples (9846-1, 9677-1, 9848-1) were geochemically analyzed (Figure 1b). In thin section, banded schists are characterized by granoblastic quartz-rich bands, that include sub-equant to elongate quartz grains, interspersed albite, and tabular biotite grains; occasionally, detrital quartz and feldspar grains are preserved. These quartzrich bands alternate with biotite-rich bands defined by deformed biotite grains with quartz, feldspar, and muscovite inclusions. Centimeter- to decimeter-scale F1 folds with N-S to NNW-SSE trending axes (Figure 1b) and subvertical axial planes affect the compositional banding and bedding relicts. Euhedral metamorphic biotites associated with $F_{1}$ folds define an axial planar disjunctive cleavage $\left(\mathrm{S}_{1}\right)$ that crosscuts the compositional banding.

\section{Results}

Geochemistry can be used to constrain the provenance and tectonic setting of sedimentary and metasedimentary rocks if their original whole-rock composition was not significantly altered during diagenesis, weathering, and/or metamorphism, (McLennan et al., 1993). In metamorphic rocks, immobile trace elements and REE are particularly reliable in the study of their provenance and depositional setting (McLennan, 1989; McLennan et al., 1990; 1993; Girty et al., 1994).

\subsection{Weathering and sorting}

The degree of weathering can be quantitatively measured with the Chemical Index of Alteration (Nesbitt and Young, 1982), defined as $\mathrm{Al}_{2} \mathrm{O}_{3} /\left[\mathrm{Al}_{2} \mathrm{O}_{3}+\mathrm{CaO}^{*}+\mathrm{Na}_{2} \mathrm{O}+\mathrm{K}_{2} \mathrm{O}\right]$ $\times 100$ (molar contents, with $\mathrm{CaO}^{*}$ being $\mathrm{CaO}$ content in the silicate fraction of the sample). The CIA measures the extent to which feldspars have been transformed into aluminous clays depleted in $\mathrm{Ca}, \mathrm{Na}$, and $\mathrm{K}$ relative to the unweathered source. On a scale of $40-100$, unweathered igneous rocks have CIA values of 45 - 55, while values for moderately weathered shales range from 70 to 75 CIA. Intense weathering of feldspars in a rock results in high concentrations of residual clays (kaolinite and/or gibbsite), producing CIA values close to 100 . CIA values for our samples (Table 1) vary between $\sim 52$ and 72 , with an average value of $57(n=20)$ for metapsammites, and a mean of 67 for metapelitic samples $(n=11)$, thus showing a moderate degree of weathering. High-silica concentration in metapsammitic samples could mask the alteration, resulting in low CIA values (Nesbitt and Young, 1982).

Our data and previously published geochemical data for metapelitic and metapsammitic samples from the Puncoviscana and Ancasti formations (Zimmermann, 2005; Willner et al., 1985; Do Campo and Ribeiro-Guevara, 2005) are plotted on a ternary diagram using molecular proportions of $\mathrm{Al}_{2} \mathrm{O}_{3}-\left(\mathrm{CaO}^{*}+\mathrm{Na}_{2} \mathrm{O}\right)-\mathrm{K}_{2} \mathrm{O}(\mathrm{A}-\mathrm{CN}-\mathrm{K}$ diagram; Figure $2 \mathrm{a}$ and $2 \mathrm{~b}$ ) to evaluate deviation of the composition of the metasedimentary rocks from their original source (Nesbitt and Young, 1984; 1989). In this plot, an ideal trend almost parallel to the $\mathrm{Al}_{2} \mathrm{O}_{3}-\left(\mathrm{CaO} *+\mathrm{Na}_{2} \mathrm{O}\right)$ axis from a fresh unweathered homogeneous source indicates no significant change in the metasedimentary rocks $\left(\mathrm{CaO}^{*}+\mathrm{Na}_{2} \mathrm{O}\right)$ and $\mathrm{K}_{2} \mathrm{O}$ ratio with respect to the source. Our samples define a general trend toward illite-muscovite compositions (Figure 2a). K-feldspar is generally scarce in Puncoviscana Fm. metaclastic rocks (Do Campo and Ribeiro-Guevara, 2005; Zimmermann, 2005), and the composition of plagioclase is mostly albitic (Do Campo and Nieto, 2003). Therefore, the relatively high $\mathrm{K}$ content in the samples may be related to the transformation of aluminous clay minerals to illite (Fedo et al., 1995) or to secondary loss of Ca with respect to the parental material in the silicate fraction. Additionally, in an $\mathrm{A}-\mathrm{CN}-\mathrm{K}$ triangular plot, the intersection of the weathering trend with the feldspar join can be used to constrain initial compositions of source rocks (Fedo et al., 1995). The intersection of the weathering trend defined by our samples with the feldspar join suggests a source rock with a plagioclase/K-feldspar ratio of approximately $4: 2$ (Figure 2a). This indicates that, according to the present A-CN-K values, our sample set may have been derived from weathering of granodioritic and/or granitic sources. This interpretation has to be considered with caution, since some mobilization of alkalis may have occurred.

The index of compositional variability (ICV $\left.=\left[\mathrm{Fe}_{2} \mathrm{O}_{3}+\mathrm{K}_{2} \mathrm{O}+\mathrm{Na}_{2} \mathrm{O}+\mathrm{CaO}+\mathrm{MgO}+\mathrm{TiO}_{2}\right] / \mathrm{Al}_{2} \mathrm{O}_{3}\right)$ measures the maturity of a sample based on the abundance 

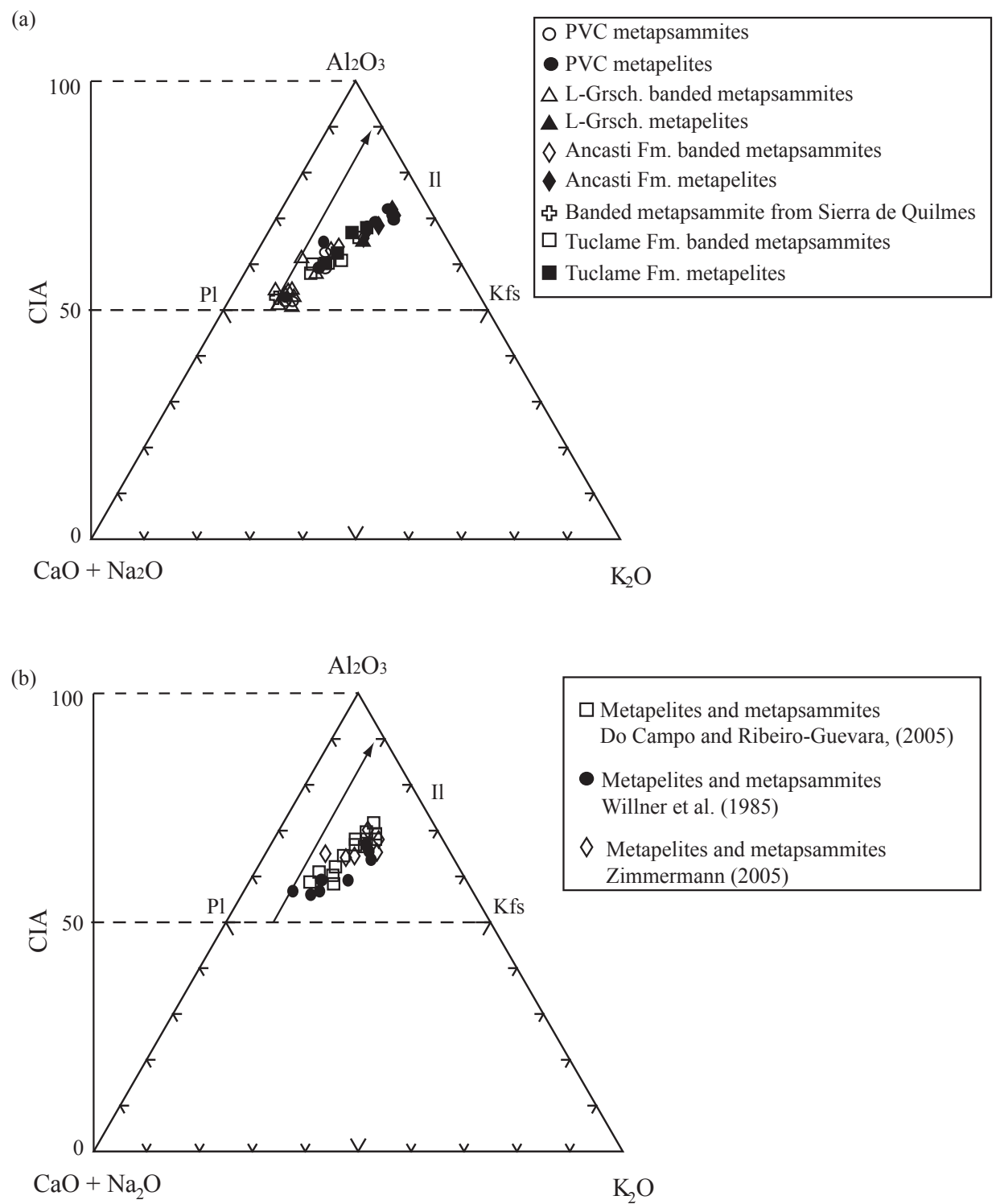

Figure 2. A-CN-K and CIA plot (after Fedo et al., 1995) for the Puncoviscana Fm. and higher-grade related rocks showing their weathering trend. Arrow is an ideal weathering trend for upper continental crust. PVC, Anchizone-grade Puncoviscana Fm.; L-Grsch., Low-greenschist facies metaclastic rocks; Il, illite; Kfs, alkali feldspar; Pl plagioclase; CIA after Nesbitt and Young (1982). (a) Samples investigated in this study. (b) Metapsammitic and metapelitic samples of the Puncoviscana Fm. from Zimmermann (2005), and Do Campo and Ribeiro-Guevara (2005). Also included are data for metapsammitic and metapelitic samples from the Ancasti Fm. from Willner et al. (1985).

of alumina relative to other major cations (Cox et al., 1995). Non-clay minerals have higher ICV values than clay minerals and therefore, ICV values will decrease with increasing degree of weathering and/or maturity in the sample. Our samples display an average ICV $=1.03$ (range $=0.87-1.24$ ), suggesting moderate weathering and/ or maturity of the source.

$\mathrm{Zr} / \mathrm{Sc}$ ratios, considered good indicators of sediment recycling, show significant variation in our samples (Table 1), ranging between 7.74 and 72.63 . Seven samples of anchizone and greenschist-grade banded metapsammites show the highest zircon enrichment with $\mathrm{Zr} / \mathrm{Sc}>30$ ratios (Table 1). Non-recycled sediments show a simple positive correlation between $\mathrm{Th} / \mathrm{Sc}$ and $\mathrm{Zr} / \mathrm{Sc}$, while recycled sediments show a more rapid increase in $\mathrm{Zr} / \mathrm{Sc}$ than in $\mathrm{Th} /$ Sc due to zircon enrichment (McLennan et al., 1993). The general $\mathrm{Th} / \mathrm{Sc} v s . \mathrm{Zr} / \mathrm{Sc}$ trend defined by our metapsammitic samples and previously published data for the Puncoviscana Fm. (Zimmermann, 2005, and Do Campo and RibeiroGuevara, 2005) is consistent with zircon concentration (Figure 3). In an $\mathrm{Al}_{2} \mathrm{O}_{3}-\mathrm{TiO}_{2}$ - $\mathrm{Zr}$ plot (García et al., 1994) low-grade metaclastic samples define a trend toward the $\mathrm{Zr}$ apex, suggesting zircon accumulation (Figure 4). High $\mathrm{TiO}_{2}$ values (Table 1) point to concentration of rutile and ilmenite. Relatively high REE concentrations in our lowgrade samples (Table 1) compared to UCC values (average 


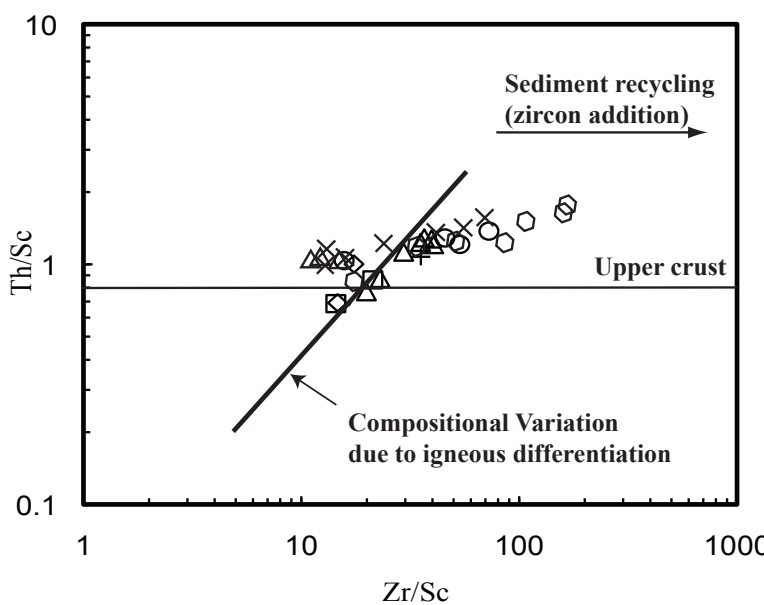

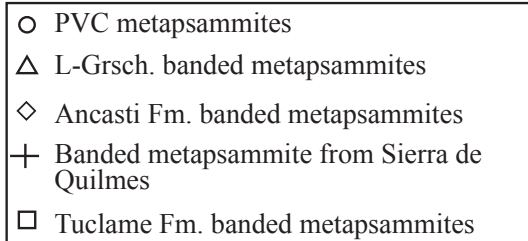

\begin{aligned} & \hline Metapsammites \\ & Do Campo and Ribeiro-Guevara (2005) \\ &$\times$ Metapsammites \\ & Zimmermann (2005) \end{aligned}

000

Figure 3. Th/Sc vs. Zr/Sc provenance and recycling discrimination plot (after McLennan et al., 1990) for Puncoviscana Fm. and higher-grade related metapsammitic rocks. $\mathrm{Th} / \mathrm{Sc}>0.8$ reflects provenance of samples from the upper continental crust (McLennan, 2001). High $\mathrm{Zr} / \mathrm{Sc}$ ratios in low-grade psammitic samples suggest a higher degree of recycling. PVC, Anchizone-grade Puncoviscana Fm.; L-Grsch., Low-greenschist facies metaclastic rocks. Also included are data for metapsammitic samples of the Puncoviscana Fm. from Zimmermann (2005), and Do Campo and Ribeiro-Guevara (2005).

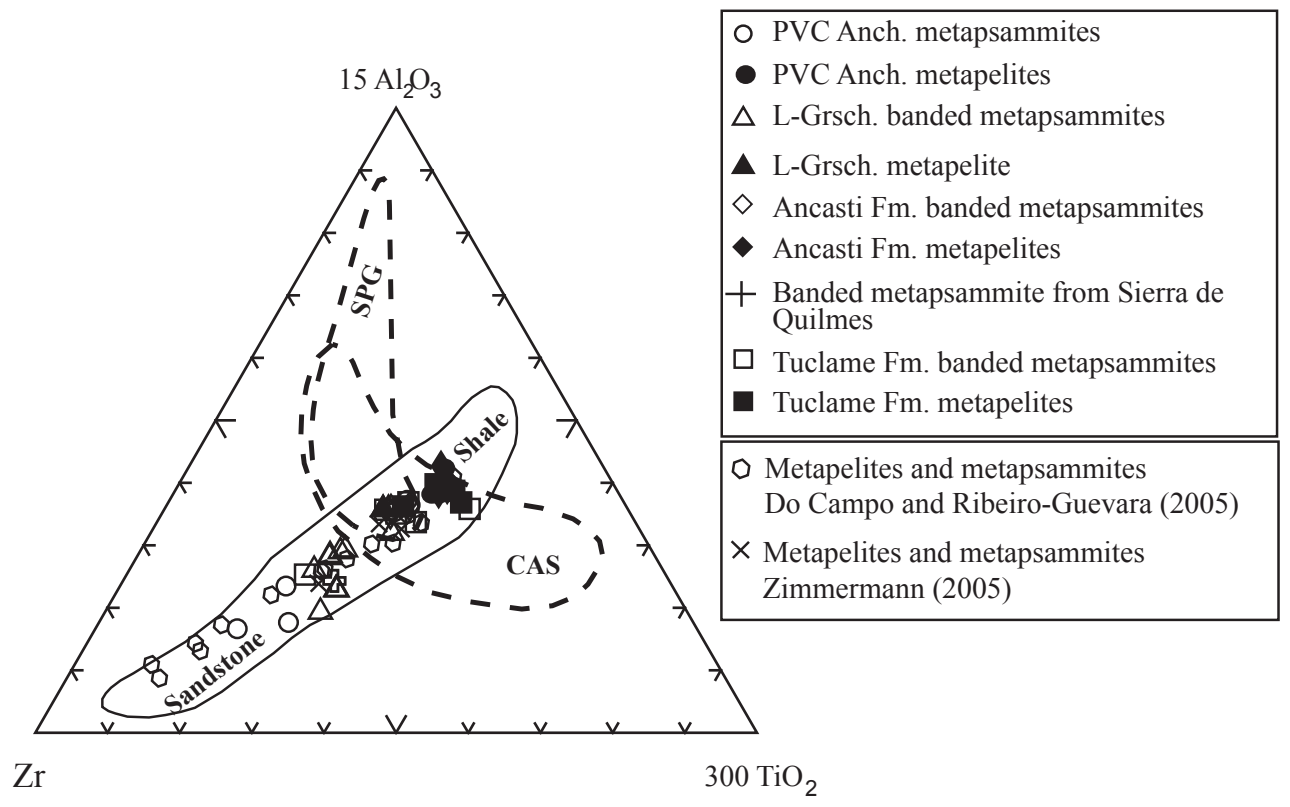

Figure 4. Al-Ti-Zr triangular diagram (after García et al., 1994) for the Puncoviscana Fm. and higher-grade related rocks. PVC, Anchizone-grade Puncoviscana Fm.; L-Grsch., Low-greenschist facies metaclastic rocks. Solid contour encloses the compositions of the samples. CAS, Calc-alkaline suites; SPG, strongly peraluminous granites.

$\sum \mathrm{REE}=146$; McLennan, 1989) are also consistent with enrichment in heavy minerals.

High concentration of heavy minerals in sedimentary and metasedimentary rocks can be attributed to either, recycling of sediments or hydraulic sorting. In our samples, resistant heavy minerals include zircon, rutile, and ilmenite. V and $\mathrm{Ti}$ are mainly present in ilmenite and rutile. $\mathrm{V}$ and Ti show little correlation with Zr. Ilmenite is less resistant than zircon over multiple cycles of transport and weathering, and thus, the high concentration of zircon in some of the psammitic samples is likely due to recycling. Metapsammitic samples display a relatively wide range of $\mathrm{TiO}_{2}-\mathrm{Zr}$ variations in an $\mathrm{Al}-\mathrm{Ti}-\mathrm{Zr}$ ternary diagram (Figure 4 ) thus supporting some reworking and recycling particularly in the low-grade rocks (García et al., 1994).

\subsection{Provenance}

Our samples are characterized by a chemical composition similar to the upper continental crust (UCC, McLennan et al., 1990; McLennan, 2001; Table 1). However, compared to UCC, metapelitic samples are more enriched in $\mathrm{K}, \mathrm{Rb}$, 
U, V, Cs, Cr, Ti, Y, La, Ce, and Sc, and depleted in Sr, Nb, and Ta. Banded metasammitic samples are characterized by enrichment in $\mathrm{Cs}, \mathrm{V}, \mathrm{Cr}$, and depletion in $\mathrm{Sr}, \mathrm{Ba}, \mathrm{Ta}$ and $\mathrm{Nb}$ with respect to UCC. Few low-grade banded metapsammitic samples are enriched in $\mathrm{Zr}$ and $\mathrm{Hf}$ with respect to UCC.

Sc, Th, Zr, REE, and high field strength trace elements (HFSE) are reliable chemical elements in provenance analysis of sediments and metasedimentary rocks due to their insolubility and immobile character during transport, diagenesis, weathering, and metamorphism (McLennan and Taylor, 1991; McLennan et al., 1995). Element ratios, such as $\mathrm{Cr} / \mathrm{V}, \mathrm{La} / \mathrm{Sc}, \mathrm{Th} / \mathrm{Co}, \mathrm{Th} / \mathrm{Sc}, \mathrm{Cr} / \mathrm{Th}$, and $\mathrm{Eu} / \mathrm{Eu}^{*}$, are particularly useful in the study of the chemical composition of the source rocks (Taylor and McLennan, 1985; McLennan et al., 1990; Cullers, 1994; Girty et al., 1994). Additionally, incompatible and compatible element ratios are diagnostic in the identification of felsic and mafic source components (Cullers, 1994; Cox et al., 1995; Fedo et al., 1996).

$\mathrm{The} \mathrm{Th} / \mathrm{Sc}$ ratio is a reliable marker for source composition and the identification of mafic source components (McLennan et al., 1990; McLennan and Taylor, 1991). Th is highly incompatible, and more abundant in crustal sources. Thus, the $\mathrm{Th} / \mathrm{Sc}$ ratio will be high in rocks derived from the crust and low in rocks with a mantle origin. Our samples show $\mathrm{Th} / \mathrm{Sc}$ ratios between 0.69 and 1.2 (average 0.95), consistent with upper crustal compositions (average $\mathrm{Th} / \mathrm{Sc}$ ratio for $\mathrm{UCC}=0.79$, McLennan, 2001). Low-grade banded metapsammites generally display higher
$\mathrm{Th} / \mathrm{Sc}$ ratios than banded metapsammites from Sierras de Ancasti and Córdoba (Table 1), likely indicating a higher sedimentary input from more evolved sources compared to higher-grade samples. Generally, high $\mathrm{Rb} / \mathrm{Sr}$ ratios $(74 \%$ of our samples show $\mathrm{Rb} / \mathrm{Sr}$ ratios $>0.80$ ) and low $\mathrm{Cr} / \mathrm{V}$ ratios (0.61-1.03) also point to non-mafic sources (McLennan et al., 1993). $\mathrm{Cr} / \mathrm{Th}$ ratios (average $6.28 \pm 1.4$ ) suggest felsic sources (Cullers, 1994). These ratios are generally lower in anchizone-grade (average $\mathrm{Cr} / \mathrm{Th}=4.70$ ) and lowgreenschist facies banded metapsammites (average $\mathrm{Cr} / \mathrm{Th}=$ 5.81) than in higher-grade metapsammitic samples (Ancasti Fm. average $\mathrm{Cr} / \mathrm{Th}=6.47$; Tuclame $\mathrm{Fm}$. average $\mathrm{Cr} / \mathrm{Th}=$ 8.56). Eu/Eu* values in our samples (average $0.67 \pm 0.06$ ) point to felsic sources (Cullers, 1994); K/Rb ratios (between 188 and 221) are close to those from typical differentiated magmatic suites (average ratio $=230$; Shaw, 1968).

$\mathrm{La} / \mathrm{Th}$ ratios are useful indicators of mafic or felsic source components, while Hf typically reveals the degree of recycling. On a La/Th vs. Hf plot ( Floyd and Leveridge, 1987), a large group of metapsammitic samples show La/ Th ratios and Hf contents that are compatible with evolved ("acidic arc") sources and close to average values for post-Archean average Australian Shale (PAAS; Taylor and McLennan, 1985), North American Shale Composite (NASC; Gromet et al., 1984), and UCC (Figure 5). Several anchizone-grade and greenschist-facies banded metapsammitic samples display high Hf concentrations (Figure 5), defining a trend that possibly reflects derivation

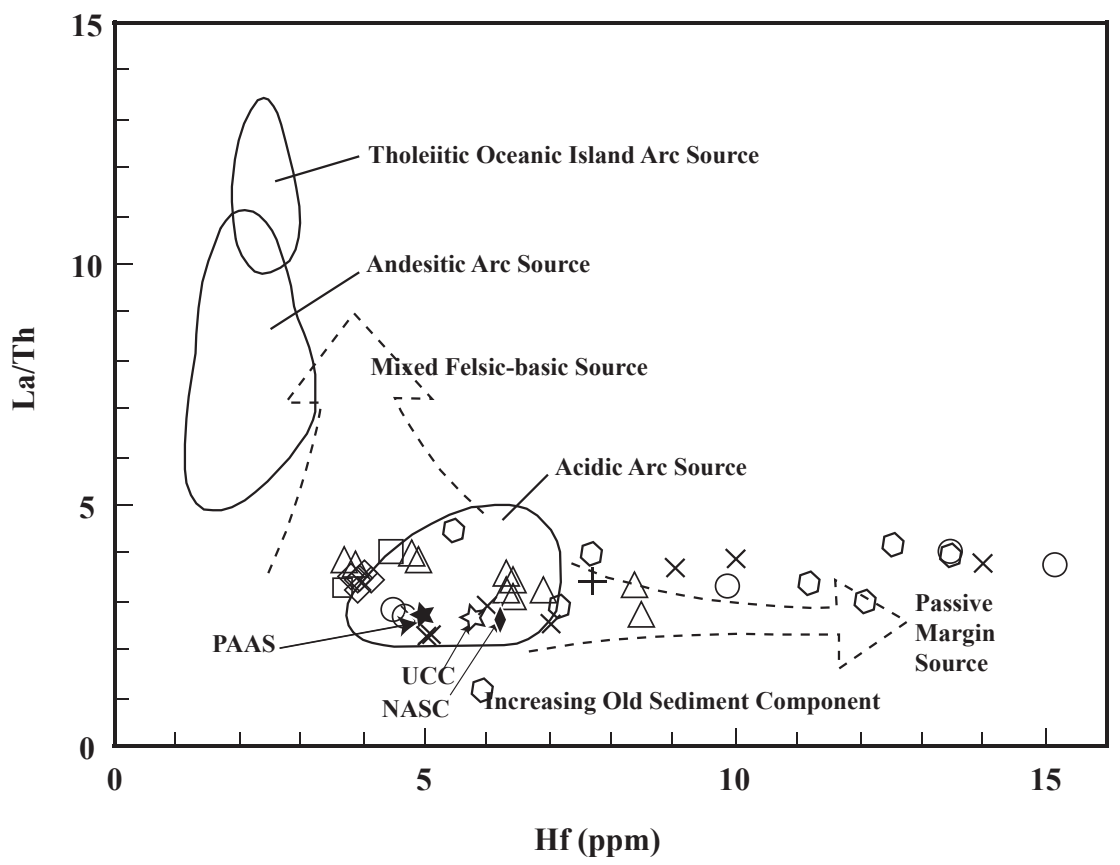

Figure 5. La/Th versus Hf tectonic setting discrimination plot (compositional fields after Floyd and Leveridge, 1987) for the Puncoviscana Fm. and highergrade related metapsammitic rocks. Most samples reflect an acidic arc source, and plot around average upper continental crust compositions (UCC after McLennan et al., 1990 and McLennan, 2001; marked with an empty star). Low-grade metapsammites show high Hf concentrations. PAAS, Post-Archean Australian Shales (after Taylor and McLennan, 1985; represented as a solid star); NASC, North American Shale Composite (after Gromet et al., 1984; plotted as a solid diamond). The remaining symbols as in Figure 3. 
from an old/recycled sediment component typical of passive margin sources or the progressive dissection of an arc.

The average concentration of total REE for our samples (average $\sum \mathrm{REE}=175$ ) is similar to PAAS (average $\sum \mathrm{REE}$ $=181$; Taylor and McLennan, 1981) and higher than UCC values (average $\sum \mathrm{REE}=146$; McLennan, 2001). $\sum \mathrm{REE}$ values for anchizone-grade metapsammites are particularly high (average $\sum \mathrm{REE}=194$ ) compared to the rest of the samples (Table 2); anchizone and greenschist-grade metapsammitic samples generally show a higher HREE content than the rest of samples (Table 1).

Chondrite-normalized REE patterns for the analyzed samples are characterized by significant LREE enrichment, negative Eu anomalies, and relatively flat HREE (Figure 6), typical of upper crustal rocks (McLennan et al., 1990). REE patterns are generally fractionated, with an average $(\mathrm{La} / \mathrm{Yb}) n$ value of $7.4 \pm 1.15$. Anchizone-grade banded metapsammites exhibit the largest fractionation (average $(\mathrm{La} / \mathrm{Yb}) \mathrm{n}=8.46$; Table 2 ) and Tuclame banded metapsammites the lowest fractionation (average $(\mathrm{La} / \mathrm{Yb})$ $\mathrm{n}=6.37$; Table 2$)$. ( $\mathrm{La} / \mathrm{Sm}) \mathrm{n}$ ratios range from $2.79-3.88$ (average $3.43 \pm 0.35$ ) indicating some LREE fractionation (Table 1), which is largest in anchizone-grade banded metapsammites (average $(\mathrm{La} / \mathrm{Sm}) \mathrm{n}=3.79$; Table 2 ) and lowest in Tuclame banded metapsammites (average (La/Sm) $\mathrm{n}=2.92$; Table 2$).(\mathrm{Gd} / \mathrm{Yb}) \mathrm{n}$ ratios vary between $1.11-1.77$ (average $1.52 \pm 0.16$ ) consistent with nearly flat chondritenormalized HREE patterns. $\mathrm{Ce} / \mathrm{Ce}{ }^{*}$ values are $\sim 1$.

Our samples exhibit moderate to significant $\mathrm{Eu} / \mathrm{Eu}^{*}$ anomalies (Table 1; Table 2), with values between 0.54 and 0.79 (average $\mathrm{Eu} / \mathrm{Eu}^{*}=0.67$ ). $89 \%$ of the samples display $\mathrm{Eu} / \mathrm{Eu}^{*}>0.6$, typical of source rocks affected by intra-crustal differentiation processes and consistent with derivation from UCC sources (McLennan, 1989; McLennan et al., 1990; McLennan, 2001).

\subsection{Tectonic setting}

The chemical composition of the source rock is a function of the tectonic setting, and exerts major control on the chemistry of sedimentary and metasedimentary rocks. Therefore, the geochemistry of sediments and metasedimentary rocks can be directly related to plate tectonic processes and has been traditionally used to identify their tectonic setting (Taylor and McLennan, 1985; Roser and Korsch, 1986; McLennan and Taylor, 1991). Trace elements, particularly those that are relatively immobile, with low residence times in seawater (i.e. $\mathrm{La}, \mathrm{Nd}, \mathrm{Th}, \mathrm{Zr}$, $\mathrm{Hf}, \mathrm{Nb}, \mathrm{Ti}$ ) are reliable fingerprints for tectonic setting discrimination (McLennan et al., 1990; Gu, 1996a, 1996b). On La-Th-Sc, Th-Co- Zr/10, and Th-Sc-Zr/10 plots (Bhatia and Crook, 1986; Figure 7), most data fall in the fields for "continental island-arc". A group of anchizone and greenschist-facies banded metapsammitic samples plot in the "passive margin" field or between the "continental island arc" and "passive margin" fields.

$\mathrm{La} / \mathrm{Sc}$ ratios are controlled by the mafic or felsic composition of the source: input from mafic and ultramafic source areas results in an enrichment of Sc. Additionally, $\mathrm{Ti}$ and Sc reflect the volcanic vs. mantelic compositional influence in the source. $\mathrm{Zr}$ and La provide information about the degree of recycling (McLennan et al., 1990). Thus, Ti/ $\mathrm{Zr} v s . \mathrm{La} / \mathrm{Sc}$ plots are helpful in the identification of the relative contribution of magmatic $v s$. recycled sources and

Table 2. Comparison of average ratios and total REE content in banded metapsammitic samples from the Puncoviscana Fm. and higher-grade related rocks with averages in sands from modern tectonic environments. Upper continental crust (UCC) ratios from McLennan, 2001.

\begin{tabular}{|c|c|c|c|c|c|}
\hline Tectonic setting discriminators & $(\mathrm{La} / \mathrm{Yb}) \mathrm{n}$ & $(\mathrm{La} / \mathrm{Sm}) \mathrm{n}$ & $(\mathrm{Gd} / \mathrm{Yb}) \mathrm{n}$ & $\mathrm{Eu} / \mathrm{Eu}^{*}$ & $\sum \mathrm{REE}$ \\
\hline Passive Margin* & 9.80 & 3.67 & 1.40 & 0.74 & 106.96 \\
\hline Back Arc Basin* & 6.50 & 2.95 & 1.30 & 0.79 & 83.63 \\
\hline Continental Arc Basin* & 7.18 & 3.19 & 1.30 & 0.76 & 113.49 \\
\hline Fore Arc Basin* & 2.93 & 1.82 & 1.12 & 0.89 & 55.90 \\
\hline Fore Arc Basin ${ }^{+}$ & 9.11 & 5.77 & 1.61 & 0.73 & 134.00 \\
\hline Ave. PVC Anc. metapsammites** & 8.46 & 3.79 & 1.53 & 0.62 & 194.49 \\
\hline Ave. L-Grsch. Banded metapsammites** & 7.40 & 3.39 & 1.54 & 0.70 & 144.77 \\
\hline Banded metapsammite from Sierra de Quilmes** & 6.82 & 3.08 & 1.63 & 0.65 & 164.83 \\
\hline Ave. Ancasti Fm. banded metapsammites** & 8.44 & 3.45 & 1.68 & 0.69 & 148.33 \\
\hline Ave. Tuclame Fm. Banded metapsammites** & 6.37 & 2.92 & 1.58 & 0.69 & 125.09 \\
\hline UCC & 9.21 & 4.20 & 1.40 & 0.65 & 146.37 \\
\hline
\end{tabular}

Note. $\left(^{*}\right)$ average data from McLennan et al., 1990; (+) average data from Mazur et al., 2010

$(* *)$ average data from this research. 

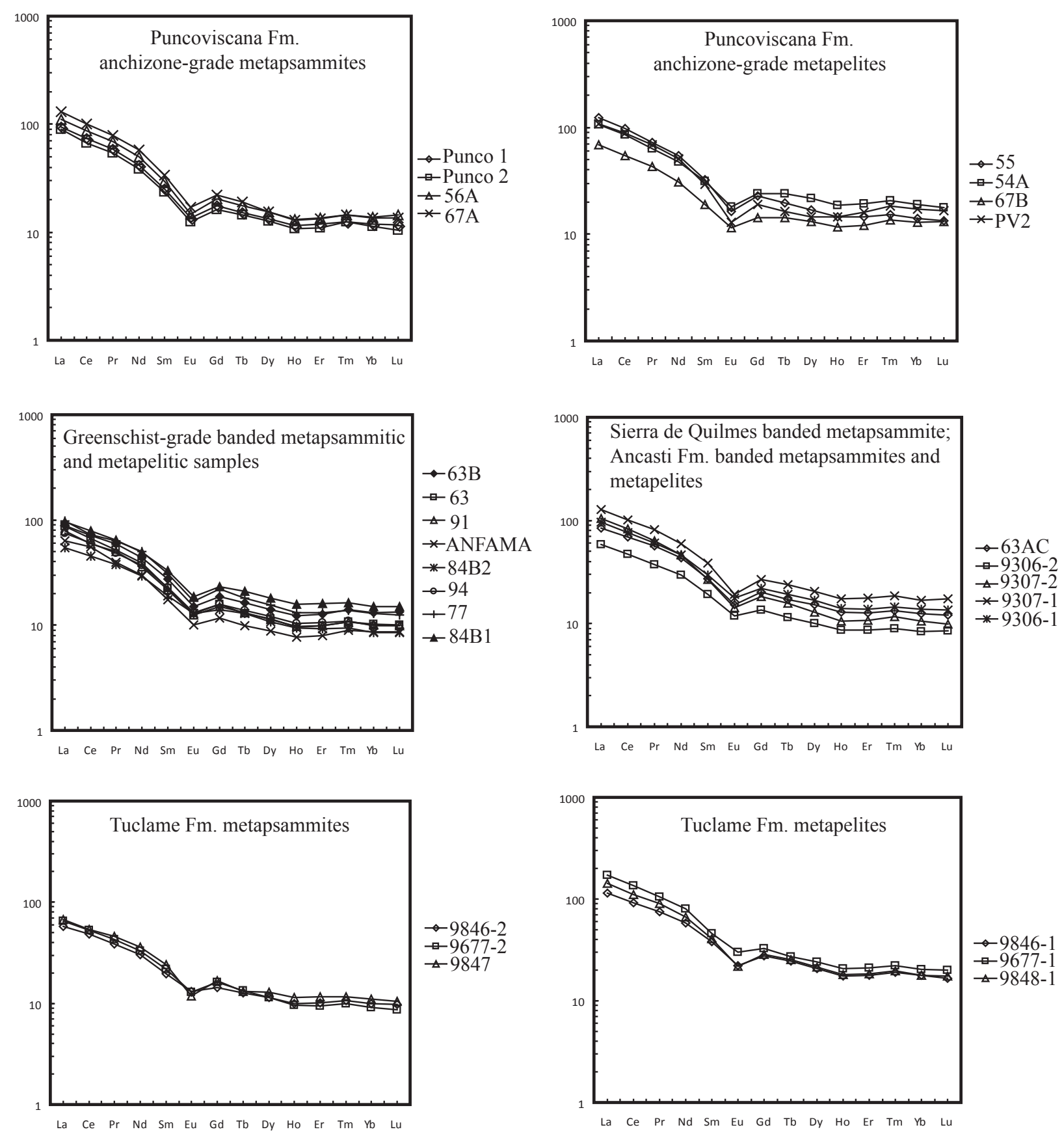

Figure 6. Chondrite-normalized REE patterns for the Puncoviscana Fm. and higher-grade related rocks. The patterns are similar to upper continental crust and post-Archean shales, with LREE enrichment, flat HREE, and significant negative Eu anomalies. Chondrite-normalizing factors from Taylor and McLennan (1985).

can discriminate successfully between different tectonic environments (Bhatia and Crook, 1986). In this diagram (Figure 8), most data plot in the fields for "active continental margin" and "continental island arc". A group of anchizone and greenschist-facies banded metapsammitic samples plot in the "passive" margin field reflecting a higher input of recycled sources.

Upper continental crust-normalized multi-element patterns are useful to discriminate the tectonic environment of greywackes (Floyd et al., 1991). Figure 9 shows UCCnormalized patterns for average values calculated from our samples, and for sandstones from common tectonic environments (average data from Floyd et al., 1991). Our samples show UCC-normalized patterns similar to those from continental arc/active margin and passive margin samples. A positive Ti-Hf-Zr-Y anomaly in our low- 
(a)

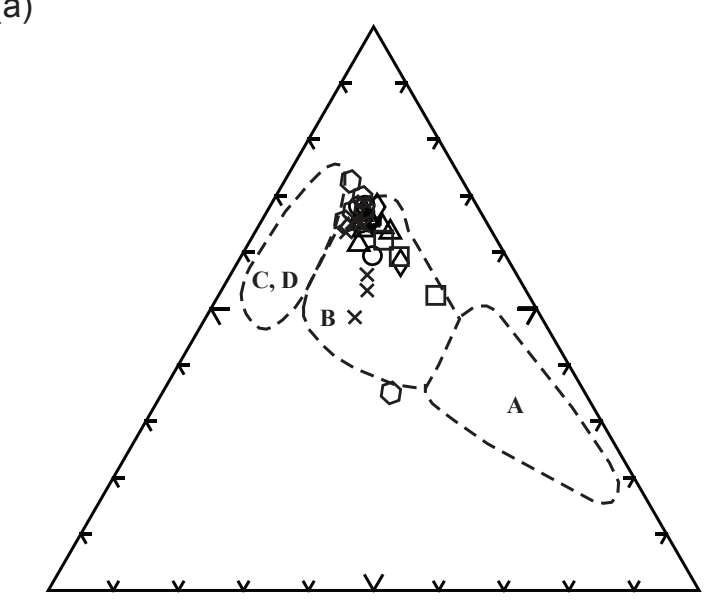

Th

(b)

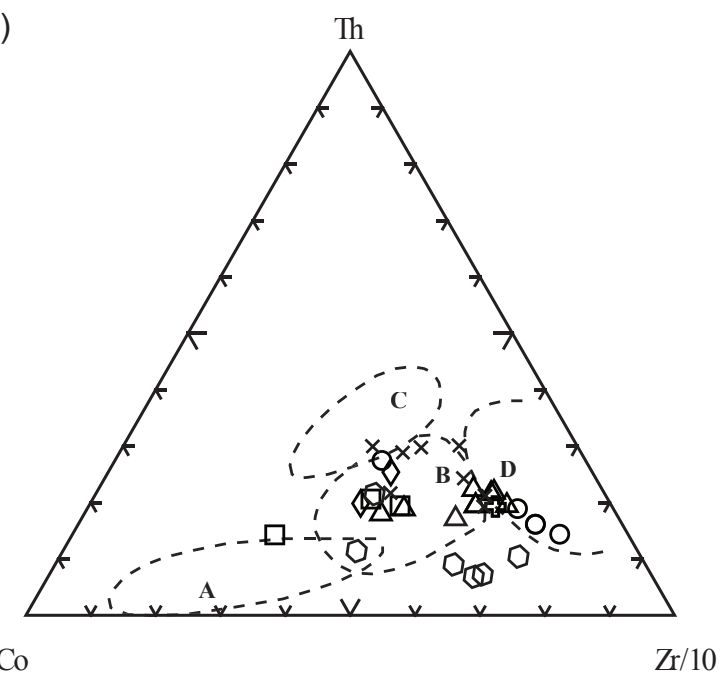

(c)

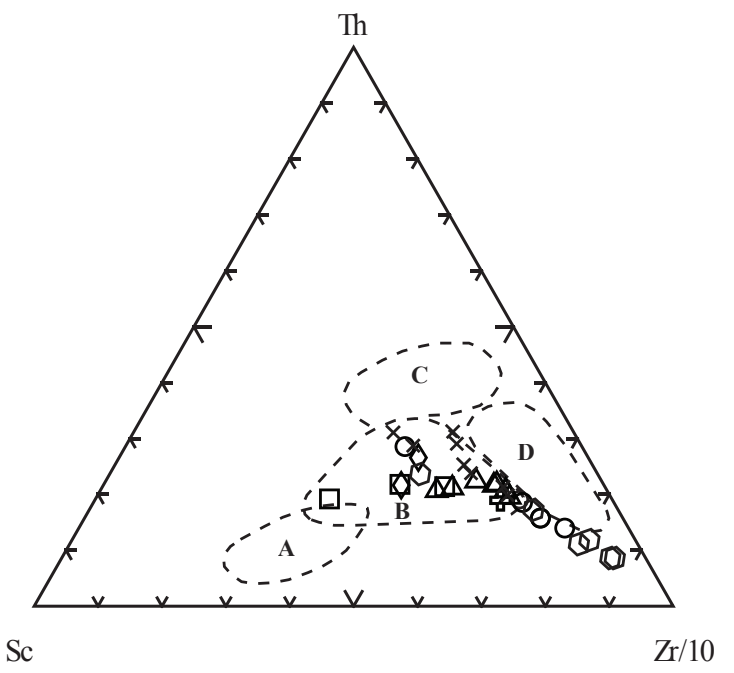

Figure 7. (a) La-Th-Sc, (b) Th-Co-Zr/10, and (c) Th-Sc-Zr/10 tectonic discrimination diagrams for the Puncoviscana Fm. and higher-grade related metapsammitic rocks. Dotted lines represent fields for sandstones from various tectonic settings (after Bhatia and Crook, 1986). A, oceanic island arc; $\mathrm{B}$, continental island arc; $\mathrm{C}$, active continental margin; D, passive margin. Symbols as in Figure 3.

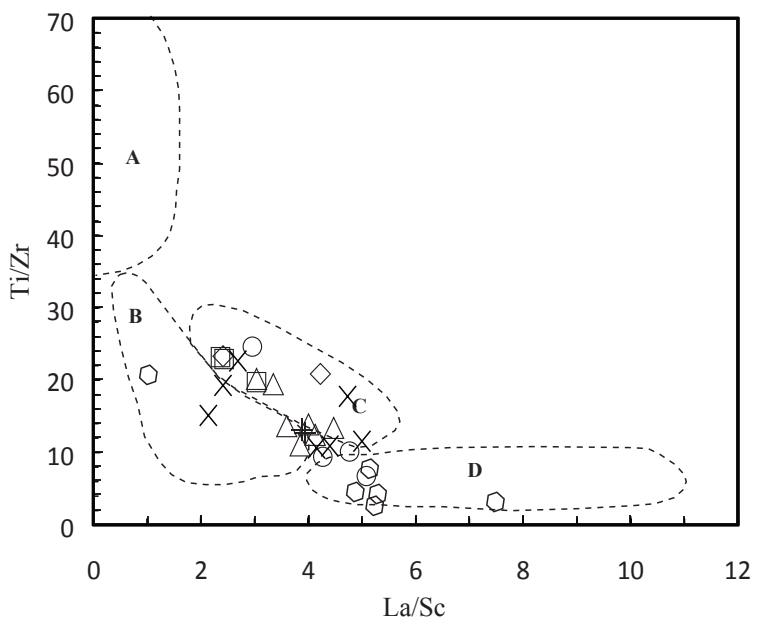

Figure $8 . \mathrm{La} / \mathrm{Sc}$ s. Ti/Zr tectonic discrimination diagram of the Puncoviscana Fm. and higher-grade related metapsammitic rocks. Dotted lines represent the fields for sandstones from various tectonic settings (after Bhatia and Crook, 1986). A, oceanic island arc; B, continental island arc; C, active continental margin; D, passive margin. Symbols as in Figure 3.

grade metapsammitic samples (Figure 9) likely reflects heavy mineral input (Floyd et al., 1991). Negative $\mathrm{Nb}-\mathrm{Ta}$ anomalies are characteristic of continental, passive margin, and subduction-related magmatic rocks (Hofmann, 1988; Floyd et al., 1991). Nb-Ta anomalies are measured by the $\mathrm{Nb} / \mathrm{Nb}^{*}$ ratio, which is typically $c .0 .15-0.30$ for subductionrelated rocks and c. 0.5 for passive margin sediments (Floyd et al., 1991). $\mathrm{Nb} / \mathrm{Nb}^{*}$ ratios in our metapsammitic samples range from 0.24 to 0.4 and are consistent with sources related to subduction-related magmatic rocks.

In Table 3, sensitive discriminators of tectonic setting such as $\mathrm{Th} / \mathrm{Sc}, \mathrm{Zr} / \mathrm{Hf}, \mathrm{La} / \mathrm{Th}, \mathrm{La} / \mathrm{Sc}$, and $\mathrm{Th} / \mathrm{U}$ ratios for the Puncoviscana Fm. and related rocks are compared to those for sandstones and greywackes from various tectonic settings (average values from Bhatia and Crook, 1986; McLennan et al., 1990; Floyd and Leveridge, 1987; Mazur et al., 2010). Average $\mathrm{Th} / \mathrm{Sc}$ ratios in anchizone and greenschist-facies metapsammites are similar to those of trailing edge (passive margin), and dissected arc greywackes (McLennan et al., 1990; Bhatia and Crook, 1986). Zr/Hf values in our samples are similar to those of "continental island arc", and "dissected arc" greywackes. $\mathrm{La} / \mathrm{Th}, \mathrm{La} / \mathrm{Sc}$, and $\mathrm{Th} / \mathrm{U}$ ratios in our samples are comparable with those of "continental arc" and "dissected arc" sandstones (Table 3).

$(\mathrm{La} / \mathrm{Yb}) \mathrm{n},(\mathrm{La} / \mathrm{Sm}) \mathrm{n},(\mathrm{Gd} / \mathrm{Yb}) \mathrm{n}$, and $\mathrm{Eu} / \mathrm{Eu}^{*}$ ratios, and $\sum$ REE are sensitive discriminators of the tectonic setting (McLennan et al., 1990). In Table 2 our samples show values for $(\mathrm{La} / \mathrm{Yb}) \mathrm{n},(\mathrm{La} / \mathrm{Sm}) \mathrm{n}$, and $\mathrm{Eu} / \mathrm{Eu}^{*}$ similar to those of sediments from "continental arc basins" and "passive margins" (Table 2; McLennan et al., 1990; McLennan, 2001). Eu anomalies in our samples are also typical for average UCC, recycled sedimentary rocks, and rocks from "differentiated continental volcanic arcs" dominated by felsic rocks that are exposed as the arc becomes dissected 


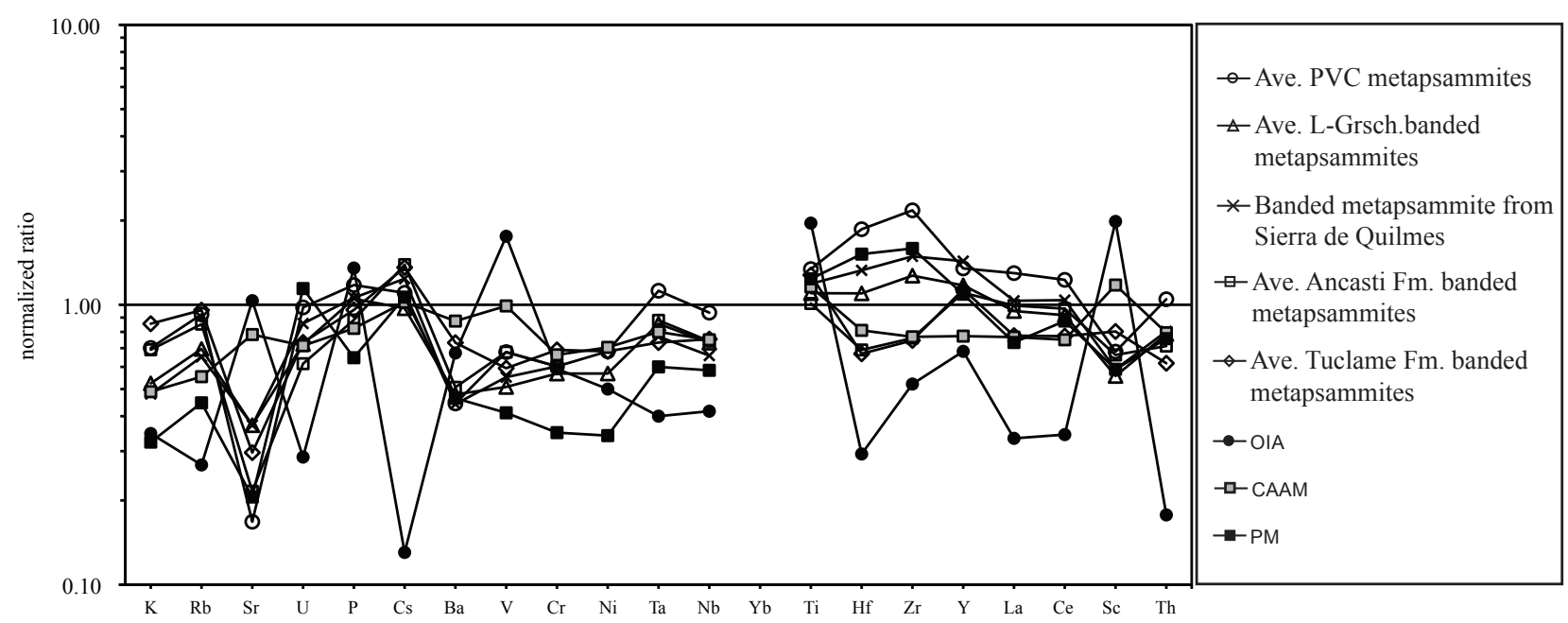

Figure 9. Upper continental crust normalized multi-element patterns for averaged greywacke data from different tectonic environments (from Floyd et al., 1991). Also plotted are normalized average values for Puncoviscana Fm. and higher-grade related metapsammitic rocks (from this study). PVC, Anchizone-grade Puncoviscana Fm.; L-Grsch., Low-greenschist facies metaclastic rocks. OIA, oceanic island arc; CAAM, continental arc + active margin; PM, passive margin. Upper continental crust normalization values from Taylor and McLennan (1985), McLennan et al., 1990, and McLennan, 2001. Puncoviscana Fm. and related samples display normalized patterns similar to those of CAAM and PM.

Table 3. Comparison of average ratios in Puncoviscana Fm. and higher-grade related rocks with averages in sands from modern tectonic environments. Upper continental crust (UCC) ratios from McLennan, 2001.

\begin{tabular}{|c|c|c|c|c|c|c|c|c|c|c|c|c|c|c|}
\hline $\begin{array}{l}\text { Tectonic setting } \\
\text { discriminators }\end{array}$ & $\begin{array}{l}\text { Continental } \\
\text { Island Arc* }\end{array}$ & $\begin{array}{c}\text { Active } \\
\text { Continental } \\
\text { Margin* }\end{array}$ & $\begin{array}{c}\text { Fore Arc } \\
\text { Basin+ }\end{array}$ & $\begin{array}{l}\text { Disected } \\
\text { Arc }+\end{array}$ & $\begin{array}{l}\text { Trailing } \\
\text { Edge*** }\end{array}$ & $\begin{array}{l}\text { Back } \\
\text { Arc** }\end{array}$ & $\begin{array}{l}\text { Fore } \\
\mathrm{Arc}^{* *}\end{array}$ & $\begin{array}{l}\text { Continental } \\
\text { Arc** }\end{array}$ & $\begin{array}{l}\text { Ave. PVC Anc. } \\
\text { metapsammites*** }\end{array}$ & $\begin{array}{l}\text { Ave. L-Grsch. Banded } \\
\text { metapsammites*** }\end{array}$ & $\begin{array}{c}\text { Banded } \\
\text { metapsammite } \\
\text { from Sierra de } \\
\text { Quilmes*** }\end{array}$ & $\begin{array}{l}\text { Ave. Ancasti Fm. } \\
\text { banded } \\
\text { metapsammites*** }\end{array}$ & $\begin{array}{l}\text { Ave. Tuclame Fm. } \\
\text { Banded } \\
\text { metapsammites*** }\end{array}$ & UCC \\
\hline $\mathrm{Th} / \mathrm{Sc}$ & 0.85 & 2.59 & 1.37 & 1.10 & 1.08 & 0.51 & 0.09 & 0.75 & 1.23 & 1.11 & 1.08 & 0.85 & 0.66 & 0.79 \\
\hline $\mathrm{La} / \mathrm{Th}$ & 2.36 & 1.77 & 2.30 & 3.55 & 4.30 & 4.41 & 12.90 & 3.35 & 3.47 & 3.45 & 3.60 & 3.84 & 3.52 & 2.80 \\
\hline $\mathrm{La} / \mathrm{Sc}$ & 1.82 & 4.55 & 3.05 & 3.92 & 4.58 & 1.68 & 0.45 & 2.11 & 4.29 & 3.78 & 3.88 & 3.32 & 2.33 & 2.20 \\
\hline $\mathrm{Th} / \mathrm{U}$ & 4.60 & 4.80 & 3.02 & 3.51 & 3.22 & 3.21 & 1.80 & 3.53 & 4.11 & 4.11 & 3.58 & 4.39 & 3.23 & 3.82 \\
\hline
\end{tabular}

Note: $(*)$ average data from Bhatia and Crook, 1986; $(+)$ average data from Floyd and Leveridge, 1987; (**) average data from McLennan et al., 1990; $(* * *)$ average data from this research.

(McLennan et al., 1993).

\section{Discussion}

Our geochemical data show that the Puncoviscana Fm. and related metasedimentary rocks have chemical compositions that reflect enrichment in incompatible elements and depletion in some compatible elements compared to UCC (McLennan, 2001). Our data also suggest that the samples are derived from a moderately weathered, felsic source, in agreement with previously published data for the Puncoviscana Fm. (Do Campo and RibeiroGuevara, 2005; Zimmermann, 2005). According to results from tectonic discriminant diagrams, REE abundances, and UCC-normalized trace element patterns, our samples are characterized by a volcanic-arc signature. The interpretation of a volcanic arc derivation on the basis of the chemical composition of metasediments must be made cautiously, since it has been shown that specific tectonic settings do not necessarily produce rocks with unique geochemical signatures (McLennan et al., 1990; Bahlburg, 1998), and the continental crust itself is made of rocks bearing an arc-like composition (Bock et al., 2000). However, the presence of volcaniclastic grains and felsic tuff beds in the Puncoviscana Fm. (Aparicio-González et al., 2010; Jezek and Miller, 1987; Zimmermann, 2005; Escayola et al., 2011) are also consistent with a volcanic arc source. Some authors describe the proportion of volcaniclastic grains as generally low (Jezek, 1990; Jezek and Miller, 1987; Zimmermann, 2005). This could be explained if most volcanic grains were weathered and dissolved to pseudomatrix (Zimmermann, 2005). Alternatively, if the source area was part of an evolved arc, denudation of volcanic levels and unroofing of the arc may have resulted in an increase of the proportion of sediments from exhumed plutonic and metasedimentary rocks, and the near absence of volcanic debris input into the basin. Recent studies based on detrital zircon ages from metasedimentary rocks of the Puncoviscana Fm. and highergrade related rocks in Sierras de Cordoba, and ages obtained from syn- to post-kinematic granites suggest that at least part of the deposition of the sediments in the Puncoviscana basin was synchronous with a nearby Pampean magmatic arc (Escayola et al., 2011; Iannizzotto et al., 2013). 
The Puncoviscana Fm. and low greenschist-facies metapsammitic samples display a chemical signature that suggests heavy mineral concentration and input of recycled sediments. This is consistent with their content of sedimentary and metamorphic lithoclasts and heavy minerals observed in thin section. In a La/Th $v s$. Hf plot, these samples show a trend to higher Hf contents, pointing to more recycled sources. This suggests a strong influence from old upper continental crust or recycled sedimentary rocks, as previously proposed by Do Campo and RibeiroGuevara (2005) for the Puncoviscana Fm. This recycled input could reflect either a deeper dissection of the arc source in the north, or a different source area with respect to the protoliths of metasedimentary rocks from Eastern Sierras Pampeanas. Nd isotope compositions and detrital zircon age maxima present in the very low- to low-grade Puncoviscana Fm. and related metaclastic rocks are similar to those in higher-grade metaclastic rocks of Eastern Sierras Pampeanas, suggesting related sources, or mixed sources with a similar TDM value (Drobe et al., 2009; Collo et al., 2009). Stronger reworking in northern areas of the basin could also explain the recycled component, but we would expect to observe higher degrees of alteration in our samples (higher CIA values). However, high silica concentration in metapsammitc samples can mask the alteration (e.g. Nesbitt and Young, 1982; Zimmermann, 2005). In a different scenario, the sediments filling the Puncoviscana basin may have been derived from source rocks with isotopic and geochemical signatures similar to those exhibited by Puncoviscana Fm. and related rocks; these source rocks may have been overlying the Rio de la Plata craton, and would be now completely eroded (Drobe et al., 2011).

In tectonic discrimination diagrams using trace elements, metapsammitic samples mostly plot in the fields of continental island-arc, or active continental margin (Figures 7 and 8), while anchizone- and greenschist-facies metapsammitic samples plot in the passive margin field. Similar results were obtained by Escayola et al. (2011) for rocks from the Puncoviscana Fm. Trace element ratios traditionally considered as good indicators of the tectonic setting ( $\mathrm{Th} / \mathrm{Sc}, \mathrm{Zr} / \mathrm{Hf}, \mathrm{La} / \mathrm{Th}, \mathrm{La} / \mathrm{Sc}$, and $\mathrm{Th} / \mathrm{U})$ in our low-grade metapsammitic samples are similar to those of sandstones from "passive margins" and "dissected arcs" (Tables 2 and 3).

Poorly sorted angular clasts in our low-grade metapsammitic samples, and the generally moderate degree of weathering observed in the Puncoviscana Fm. and related samples suggest rapid erosion and burial in a relatively close location to the source. This is compatible with dissected arc settings, characterized by rapid erosion rates and lower degrees of weathering compared to old upper crust (McLennan et al., 1993). Eu/Eu* ratios and relatively high $\mathrm{Hf}$ content in low-grade metapsammitic samples are also consistent with dissected arcs (Floyd and Leveridge, 1987; McLennan et al., 1993; Table 2). Based on petrographic analyses, Jezek (1990) previously suggested a dissected volcanic arc source for the Puncoviscana Fm.

Detrital zircon age maxima from Puncoviscana Fm. and higher-grade related rocks suggest a mixing of late Neoproterozoic-Early Cambrian (520 - 650 Ma) and late Mesoproterozoic to early Neoproterozoic ( $\sim 850-1150$ Ma) sources (Rapela et al., 1998; Adams et al., 2010, 2011; Escayola et al., 2007; Drobe et al., 2011) that likely were relatively close to the Puncoviscana basin during sedimentation. The absence of detrital zircon maxima above $2 \mathrm{Ga}$ and $\mathrm{Nd}$ model ages argues against the Rio de la Plata craton as a source for the metasediments of the Puncoviscana Fm. and higher-grade equivalents in Eastern Sierras Pampeanas (Schwartz and Gromet, 2004; Steenken et al., 2006, 2010; Adams et al., 2011; Escayola et al., 2007; Rapela et al., 2007; Drobe et al., 2009 and references therein; Escayola et al., 2011). Thus, a continental magmatic arc formed along the margin of a Mesoproterozoic craton during the Brasiliano orogeny may have been a potential source for the Puncoviscana Fm. and related rocks (Lucassen et al., 2000; Steenken et al., 2004; Escayola et al., 2007; Schwartz and Gromet, 2004; Rapela et al., 2007; Siegesmund et al., 2009; Drobe et al., 2009 and references therein). In recent works, the deposition of the Puncoviscana Fm. and related rocks would be coeval with the Pampean arc (Escayola et al., 2011; Adams et al., 2011; Iannizzotto et al., 2013). Dominant magmatic and detrital sources from exhumed Mesoproterozoic basement and Brasiliano volcanic and plutonic rocks to the east of the Puncoviscana basin are consistent with volcanic arc geochemical signatures observed in our samples, with paleocurrent directions that indicate sediment transport from the east/southeast (Jezek and Miller, 1986; Jezek, 1990; Willner, 1990), and with detrital zircon ages obtained by other authors (Rapela et al., 1998; Adams et al., 2008a , 2008b; Escayola et al., 2007; Drobe et al., 2011).

Based on isotopic analysis, an extension of the Arequipa-Antofalla massif into the Sierras Pampeanas (Lucassen et al., 2000; Steenken et al., 2004; Escayola et al., 2007; Collo et al., 2009) or the Kalahari craton and its vicinity (Schwartz and Gromet, 2004; Rapela et al., 2007; Siegesmund et al., 2009; Drobe et al., 2009 and references therein) have been proposed as a Mesoproterozoic source for the Puncoviscana and related metasedimentary rocks.

Collo et al. (2009) proposed a model in which the Puncoviscana Fm. and equivalent protoliths in Sierras Pampeanas likely were deposited as a back-arc sedimentary sequence that formed to the west of a continental Brasiliano volcanic arc developed on an extension of the ArequipaAntofalla massif. This arc was related to west dipping subduction of oceanic crust under the Mesoproterozoic Arequipa-Antofalla terrane. Consistent with this model are geochemical signatures from volcanic rocks interlayered with metasedimentary rocks of the Puncoviscana Fm. that point to a rifting or a back-arc setting (Omarini et al., 1999) and the volcanic arc geochemical signatures observed in our samples. A deeper dissection of the arc could have 
contributed to the "recycled" and/or "heavy mineral" component observed in our low-grade samples.

In alternative models proposed by Rapela et al. (2007), Casquet et al. (2008), Drobe et al. (2009), Siegesmund et al. (2010) and references therein, the Puncoviscana Fm. was a fore-arc sedimentary sequence that developed on the margin of the Kalahari craton. In these models, the Puncoviscana Fm. and higher-grade equivalents were deposited in a basin to the west of a continental-arc source (i.e. Siegesmund et al., 2009), also in agreement with the continental arc signature shown in this work, with the presence of volcanic detritus, poorly sorted angular clasts, rapid burial of the protoliths, and low CIA values of the samples. The composition of turbiditic deposits can vary among individual foreland basins from different settings (Caja et al., 2010) and therefore their signature is widely variable. Th/Sc, Zr/Hf, La/Sc, (La/Yb)n, (Gd/Yb)n, and $\mathrm{Eu} / \mathrm{Eu}^{*}$ ratios, and $\sum \mathrm{REE}$ of our metapsammitic samples (Tables 2 and 3) are similar to those of turbiditic sandstones from a Carboniferous foreland basin in Western Poland (Mazur et al., 2010). If the Puncoviscana Fm. turbiditic deposits and higher-grade equivalent metaclastic rocks represent the metasedimentary infill of a foreland basin, its detrital supply may have changed with time, mainly controlled by local tectonic processes and development of accommodation space in response to basin forming processes, as is common in foreland basin settings (Blair and Bilodeau, 1988; Haines et al., 2001; McCann and Saintot, 2003; Maidment et al., 2007). Based on the local presence of zircon maxima of ages around $520 \mathrm{Ma}$ in lower-grade metaclastic rocks of the Puncoviscana Fm. (Adams et al., 2008a) and on a previous model of Zimmermann (2005), Drobe et al. (2011) proposed a cannibalistic recycling model for the Puncoviscana Fm. Exhumation of deep crustal levels due to propagation of thrust belts in the foreland basin would provide sources for the recycled basin infill in shallow levels of the Puncoviscana basin and would account for the "recycled" signature observed in the low-grade metaclastic rocks.

The maximum age of sedimentation has been dated as 530 - 636 Ma (Lork et al., 1990; Adams et al., 2008a, 2008b) and ca. $537 \mathrm{Ma}$ (Escayola et al., 2011) in the Puncoviscana Fm., ca. 600 - $760 \mathrm{Ma}$ in Sierras de Córdoba (Rapela et al., 1998; Schwartz and Gromet, 2004; Escayola et al., 2007), and 570 - $680 \mathrm{Ma}$ in the Ancasti Fm. (Rapela et al., 2007; Murra et al., 2011). Based on detrital zircons and latesyn- or post-tectonic granitic intrusions, Escayola et al. (2011) constrained the Pampian deformation between $c a$. 537 and $524 \mathrm{Ma}$ in northern localities of the Puncoviscana Fm. Metamorphic ages of the Pampean event have been determined as ca. 540 - 520 Ma in Sierras de Córdoba, (U/Pb zircon ages; Sims et al., 1998; Rapela et al., 1998). Intrusion of 536 - 520 Ma calc-alkaline syn- and posttectonic granites in the low-grade folded Puncoviscana Fm. or the emplacement of the $530 \pm 3 \mathrm{Ma}$ calc-alkaline Sierra del Norte batolith (U-Pb zircon ages, Rapela et al., 1998) in folded metasedimentary rocks of Sierras de Córdoba further constrain the age of the Pampean deformation.

Despite local effects of a high-temperature Ordovician metamorphic event that becomes more prevalent to the south and west of the Pampean orogen (Figure 1) and Tertiary brittle deformation that locally overprints and completely reorientates older structures, the style and sequence of structures and microstructures of the metasedimentary rocks remains consistent in all the studied localities: a compositional banding sub-parallel to bedding or relict bedding is folded into chevron structures $\left(\mathrm{F}_{1}\right)$ that are characterized by an associated fold-related cleavage $\left(\mathrm{S}_{1}\right)$ that is better developed with increasing metamorphic grade. The symmetric character of the folds, and their consistent geometry and trend, suggest that Pampean chevron folding and metamorphism were related to mainly orthogonal compression in the studied localities (Piñán-Llamas and Simpson, 2006). However, more recent structural studies in Sierras de Cordoba propose a compressive Early Cambrian deformational history that consists of a D1, characterized by folds with N-S to NE-SW trending axes and dextral mylonites, and a subsequent D2 with development of local dextral shear zones in some granites (von Gosen and Prozzi, 2010). Iannizzotto et al. (2013) suggest that dextral transpression was active at c. $537 \mathrm{Ma}$ and was complete before $530 \mathrm{Ma}$ in the Sierra del Norte batholith. Pampean deformation was likely due to east-dipping subduction along the western margin of the Puncoviscana basin, consistent with the presence of a NNE-trending series of Cambrian calc-alkaline granites to the east of the Puncoviscana Fm. ('Pampean arc' of Lira et al., 1997; Rapela et al., 1998; Siegesmund et al., 2010 and references therein). In the Córdoba area, Pampean convergence ended with significant post-tectonic 515 - $520 \mathrm{Ma}$ S-type peraluminous plutonism (e.g. Rapela et al., 1998, 2002; Simpson et al., 2003) that has been interpreted as related to eastward subduction of a mid-ocean ridge (Sims et al., 1998; Gromet and Simpson, 1999; Siegesmund et al., 2010 and references therein). This subduction likely ended with the collision and accretion of Western Sierras Pampeanas (Rapela et al., 2007; Siegesmund et al., 2010 and references therein). In a model proposed by Rapela et al. (2007), and references therein, this collision was followed by right-lateral shear movements that displaced the Pampean mobile belt to its present position adjacent to the Rio de la Plata craton. In alternative models, peraluminous magmatism in the Sierra de Cordoba was the result of the accretion of a paraautochtonous continental fragment, the Pampean Terrane, with the western margin of Gondwana (Rapela et al., 1998). Ramos (2008 and references therein) considered that the Puncoviscana through was a peripheral foreland basin related to the collision of the Pampia block with the Rio de la Plata craton.

After the metamorphic peak, and during the mid- to Late Cambrian, the Pampean orogenic belt was rapidly exhumed, and eroded (Rapela et al., 1998; Baldo et al., 2006; Steenken 
et al., 2011), serving as a probable source for the Mesón Group and adjacent peripheral basins to the west (Collo et al., 2009; Drobe et al., 2009, 2011). The uplifted Pampean terrane may have acted as a barrier, preventing Brasiliano and Mesoproterozoic sediments from reaching these basins (Collo et al., 2009). Sediments in these basins were deformed, metamorphosed, and intruded by calc-alkaline magmatic complexes during the Famatinian cycle (490 - 460 $\mathrm{Ma}$ ) due to east-dipping subduction of oceanic lithosphere beneath the western border of the Pampean belt (Pankhurst et al., 1998, 2000; Saavedra et al., 1998; Dahlquist et al., 2008; Ducea et al., 2010; Otamendi et al., 2012).

\section{Conclusions}

1- Major and trace element geochemistry (i.e. Th/Sc, $\left.\mathrm{Rb} / \mathrm{Sr}, \mathrm{Cr} / \mathrm{V}, \mathrm{Cr} / \mathrm{Th}, \mathrm{Zr} / \mathrm{Sc}, \mathrm{Th} / \mathrm{Sc}, \mathrm{Eu} / \mathrm{Eu}^{*}\right)$ indicates that the Puncoviscana Fm. and higher-grade related metaclastic rocks are characterized by moderate degrees of weathering (low CIA and high ICV values) and that metaclastic materials were likely derived from predominantly uppercrust felsic sources.

2- The overall geochemical fingerprints for all analyzed samples, including concentrations of $\mathrm{La}, \mathrm{Th}, \mathrm{Sc}, \mathrm{Zr}, \mathrm{La} / \mathrm{Sc}$, $\mathrm{Nb} / \mathrm{Nb}^{*}$, and $\mathrm{Eu} / \mathrm{Eu} *$ ratios, or UCC-normalized patterns, suggest that the Puncoviscana and related samples were deposited on a "continental island-arc" and (or) an "active continental margin" setting.

3- A heavy mineral/recycled signature, characterized by high $\mathrm{Zr} / \mathrm{Sc}$ ratios and high concentrations of HREE, Hf, Ti, and $\mathrm{Zr}$, is observed in low-grade psammitic samples. This signature, which is characteristic of passive margins or dissected arcs, could reflect the dissection of a continental arc source, a change in the source area, or a stage of stronger reworking within the depositional basin.

4- Diagnostic trace element ratios $(\mathrm{Th} / \mathrm{Sc}, \mathrm{Zr} / \mathrm{Hf}, \mathrm{La} / \mathrm{Th}$, $\left.\mathrm{La} / \mathrm{Sc}, \mathrm{Th} / \mathrm{U}, \mathrm{La}_{\mathrm{N}} / \mathrm{Yb}_{\mathrm{N}}, \mathrm{La}_{\mathrm{N}} / \mathrm{Sm}_{\mathrm{N}}, \mathrm{Gd}_{\mathrm{N}} / \mathrm{Yb}_{\mathrm{N}}\right)$, and large $\mathrm{Eu}$ anomalies, for the Puncoviscana Fm. and related rocks, are similar to those of sediments from modern continental arcs, continental island arc, and metasedimentary rocks related to dissected arcs.

5- Similarity in the style, orientation, and geometry of pre-Ordovician structures, and consistency in the sequence of deformation preserved in the Puncoviscana Fm. and higher-grade related rocks in the studied outcrops suggest a common deformation history during the Pampean orogeny.

6- Our results, in combination with previous geochronological, sedimentological, and isotopic data support a model in which the Puncoviscana and related sediments were deposited in a basin to the west of a Neoproterozoic Brasiliano or Pampean magmatic arc that formed along the margin of a Mesoproterozoic craton.

\section{Acknowledgments}

This research was partially financed through start-up funds to A.P.LL. by Indiana University-Purdue University Fort Wayne and by the Gobierno Federal de México (Secretaria de Educación Pública) through a PROMEP grant UAEHGO-PTC-325 to J. E. C. This study benefited from the logistic help and discussions with José Pablo Lopez. We appreciate constructive reviews and comments made by Dr. Verdecchia and an anonymous reviewer.

\section{References}

Aceñolaza, F.G., Toselli, A.J., 1973, Consideraciones estratigráficas y tectónicas sobre el Paleozóico inferior del Noroeste Argentino, in $2^{\circ}$ Congreso Latinoamericano de Geología, Caracas, Venezuela: Caracas, Venezuela, Editorial Zucre, 2, 755-763.

Aceñolaza, F.G., Durand, F.R., 1986, Upper Precambrian-lower Cambrian biota from the Northeast of Argentina: Geological Magazine, 123, 367-375.

Aceñolaza, F.G., Miller, H., Toselli, A.J., 2002, Proterozoic-Early Paleozoic evolution in western South America - a discussion: Tectonophysics, 354, 121-137.

Aceñolaza, F.G., Aceñolaza, G.F, 2005, La Formación Puncoviscana y unidades estratigráficas vinculadas en el Neoproterozoico Cámbrico Temprano del Noroeste Argentino: Latin American Journal of Sedimentology and Basin Analysis, 12, 65-87.

Adams, C.J., Miller, H., Toselli, A.J., Griffin, W.L., 2008a, The Puncoviscana Formation of northwest Argentina: U-Pb geochronology of detrital zircons and Rb-Sr metamorphic ages and their bearing on its stratigraphic age, sediment provenance and tectonic setting: Neues Jahrbuch für Geologie und Paläontologie, 247, 341-352.

Adams, C.J., Miller, H., Toselli, A.J., 2008b, Detrial zircon U-Pb ages of the Puncoviscana Formation, Late Neoproterozoic-Early Cambrian, of NW Argentina: Provenance area and maximun age of deposition, in $6^{\circ}$ South American Symposium on Isotope Geology, San Carlos de Bariloche, Río Negro, Argentina: Buenos Aires, INGEIS, 52.

Adams, C.J., Miller, H., Aceñolaza, F.G., Toselli, A.J., Griffin, W.L., 2011, The Pacific Gondwana margin in the late Neoproterozoicearly Paleozoic: Detrital zircon U-Pb ages from metasediments in northwest Argentina reveal their maximum age, provenance and tectonic setting: Gondwana Research, 19, 71-83.

Aparicio-González, P.A., Moya, M.C., Impiccini, A., 2010, Estratigrafía de las rocas metasedimentarias (Neoproterozoico-Cámbrico) de la Sierra de Mojotoro, Cordillera Oriental Argentina: Latin American Journal of Sedimentology and Basin Analysis, 17, 65-83.

Astini, R.A., Ramos, V.A., Benedetto, J.L., Vaccari, N.E., Cañas, F.L., 1996, La Precordillera: Un terreno exótico a Gondwana, in XIII Congreso Geológico Argent y III Congreso de Exploración de Hidrocarburos, Buenos Aires, Argentina: Buenos Aires, Asociación Geológica Argentina, Actas 5, 293-324.

Augustsson C., Rüsing T., Adams, C.J., Chmiel, H., Kocabayoglu, M., Büld, M., Zimmermann, U., Berndt, J., Kooijman, E., 2011, Detrital Quartz and Zircon Combined: The Production of Mature Sand with Short Transportation Paths Along the Cambrian West Gondwana Margin, Northwestern Argentina: Journal of Sedimentary Research, 81,284 - 298.

Bachmann, G., Grauert, B., 1986, Isotopic dating of polymetamorphic metasediments from Northwest Argentina: Zentralblatt für Geologie und Paläontologie, 1, 1257-1268. 
Bachman, G., Grauert, B., Kramm, U., Lork, A., Miller, H., 1987, El magmatismo del Cámbrico Medio/Cámbrico Superior en el basamento del Noroeste argentino: investigaciones isotópicas y geocronológicas sobre los granitoides de los complejos intrusivos de Santa Rosa de Tástil y Cañaní, in X Congreso Geológico Argentino, Tucumán, Argentina: Tucumán, Sociedad Geológica Argentina, Actas 4, 125-127.

Bahlburg H., 1998, The geochemistry and provenance of Ordovician turbidites in the Puna, in Pankhurst R.J., Rapela C.W. (eds.), The Proto-Andean margin of Gondwana: London, United Kingdom, Geological Society Special Publication, 142, 127-142.

Bahlburg, H., Hervé, F., 1997, Geodynamic evolution and tectonostratigraphic terranes of northwestern Argentina and northern Chile: Bulletin of the Geological Society of America, 109, 869-884

Baldo, E.G., Casquet, C., Pankhurst, R.J., Galindo, C., Rapela, C.W., Fanning, C., Dahlquist, J., Murra, J., 2006, Neoproterozoic Atype magmatism in the Western Sierras Pampeanas (Argentina): evidence for Rodinia break-up along a proto-Iapetus rift?: Terra Nova, 18, 388-394.

Becchio, R., Lucassen, F., Kaseman. S., Franz, G., Viramonte, J., 1999, Geoquímica y sistemática isotópica de rocas metamórfica del Paleozoico inferior. Noroeste de Argentina y Norte de Chile $\left(21^{\circ}-27^{\circ} \mathrm{S}\right)$ : Acta Geológica Hispánica, 34, 273-299.

Bhatia, M.R., Crook, K.A., 1986, Trace elements characteristics of greywackes and tectonic setting discrimination of sedimentary basins: Contributions to Mineralogy and Petrology, 92, 181-193.

Blair, T.C., Bilodeau, W.W., 1988, Development of tectonic cyclothems in rift, pull-apart and foreland basins: Sedimentary response to episodic tectonism: Geology, 16, 517-520

Bock, B., Bahlburg, H., Worner, G., Zimmermann, U., 2000, Tracing crustal evolution in the Southern Central Andes from Late Precambrian to Permian with geochemical and $\mathrm{Nd}$ and $\mathrm{Pb}$ isotope data: Journal of Geology, 108, 515-535.

Büttner, S., Glodny, J., Lucassen, F., Wemmer, K., Erdmann, S., Handler, R., Franz, G., 2005, Ordovician metamorphism and plutonism in the Sierra de Quilmes metamorphic complex: Implications for the tectonic setting of the northern Sierras Pampeanas (NW Argentina): Lithos, 83, 143-181.

Caja, M.A., Marfil, R., García, D., Remacha, E., Morad, S., Mansurbeg, H., Amorosi, A., Martínez-Calvo, C., Lahoz-Beltrá, R., 2010, Provenance of siliciclastic and hybrid turbiditic arenites of the Eocene Hecho Group, Spanish Pyrenees: implications for the tectonic evolution of a foreland basin: Basin Research, 22, 157-180.

Casquet, C., Pankhurst, R.J., Galindo, C., Rapela, C.W., Fanning, C.M., Baldo, E.G., Dahlquist, J., González-Casado, J.M., Colombo, F., 2008, A deformed alkaline igneous rock-carbonatite complex from the Western Sierras Pampeanas, Argentina: Evidence for late Neoproterozoic opening of the Clymene Ocean?: Precambrian Research, 165, 205-220.

Coira, B.L., Barber, E., 1987, Vulcanismo submarino ordovícico (Arenigiano-Llanvirniano) del Río Huaiquitina, Provincia de Salta, Argentina, in X Congreso Geológico Argentino, Tucumán, Argentina: Tucumán, Argentina, Sociedad Geológica Argentina, 305- 30 .

Coira, B.L., Manca, N., Chayle, W. E., 1990, Registros volcánicos en la Formación Puncoviscana, in Aceñolaza, F.G., Miller, H., Toselli, A.J. (eds.), El Ciclo Pampeano en el Noroeste Argentino, Serie Correlación Geológica: San Miguel de Tucumán, Argentina, Universidad Nacional de Tucumán, 4, 53-60.

Collo, G., Astini, R.A., Cawood, P.A., Buchan, C., Pimentel, M., 2009, $\mathrm{U}-\mathrm{Pb}$ detrital zircon ages and $\mathrm{Sm}-\mathrm{Nd}$ isotopic features in low-grade metasedimentary rocks of the Famatina belt: implications for late Neoproterozoic-early Palaeozoic evolution of the proto-Andean margin of Gondwana: Journal of the Geological Society, London, 166, 303-319.

Condie, K.C., 1991, Another look at rare earth elements in shales: Geochimica et Cosmochimica Acta, 55, 2527-2531.
Condie, K.C., 1993, Chemical composition and evolution of the upper continental crust: Contrasting results from surface samples and shales: Chemical Geology, 104, 1-37.

Cox, R., Low, D.R., Cullers, R.L., 1995, The influence of sediment recycling and basement composition on evolution of mudrock chemistry in the southwestern United States: Geochimica et Cosmochimica Acta, 59, 2919-2940.

Cullers, R.L., 1994, The controls on the major and trace element variation of shales, siltstones, and sandstones of Pennsylvanian - Permian age from uplifted continental blocks in Colorado to platform sediment in Kansas, USA: Geochimica et Cosmochimica Acta, 58, 4955-4972.

Dahlquist, J.A., Pankhurst, R.J., Rapela, C.W., Galindo, C., Alasino, P., Fanning, C.M., Saavedra. J., Baldo, E.G., 2008, New SHRIMP $\mathrm{U}-\mathrm{Pb}$ data from the Famatina Complex: constraining Early-Mid Ordovician Famatinian magmatism in the Sierras Pampeanas, Argentina: Geologica Acta, 6, 319-333.

Dahlquist, J.A., Rapela, C.W., Pankhurst, R.J., Fanning, C.M., Vervoort, J.D., Hart, G., Baldo, E. G., Murra, J.A,. Alasino, P.H., Colombo, F., 2012, Age and magmatic evolution of the Famatinian granitic rocks of Sierra de Ancasti, Sierras Pampeanas, NW Argentina: Journal of South American Earth Sciences, 34,10-25.

Do Campo, M., Nieto, F., 2003, Transmission electron microscopy study of very low-grade metamorphic evolution in Neoproterozoic pelites of the Puncoviscana formation (Cordillera Oriental, NW Argentina): Clay Minerals, 38, 459-481.

Do Campo, M., Ribeiro-Guevara, S.R., 2002, Geoquímica de las secuencias clásticas de la Formación Puncoviscana (Neoproterozoico, NO Argentina), proveniencia y marco tectónico, in XV Congreso Geológico Argentino, El Calafate, Argentina: Buenos Aires, Sociedad Geológica Argentina, disponible en CD.

Do Campo, M., Ribeiro-Guevara, S.R., 2005, Provenance analysis and tectonic setting of late Neoproterozoic metasedimentary successions in NW Argentina: Journal of South American Earth Sciences, 19, 143-153.

Drobe, M., López de Luchi, M.G., Steenken, A., Frei, R., Naumann, R., Wemmer, K., Siegesmund, S., 2009, Provenance of the late Proterozoic to early Cambrian metaclastic sediments of the Sierra de San Luis (Eastern Sierras Pampeanas) and Cordillera Oriental, Argentina: Journal of South American Earth Sciences, 28, 239-262.

Drobe, M., López de Luchi, M., Steenken, A., Wemmer, K., Naumann, R., Frei, R., Siegesmund, S., 2011, Geodynamic evolution of the Eastern Sierras Pampeanas (Central Argentina) based on geochemical, $\mathrm{Sm}-\mathrm{Nd}, \mathrm{Pb}-\mathrm{Pb}$ and SHRIMP data: International Journal of Earth Sciences, 100, 631-657..

Ducea, M.N., Otamendi, J.E., Bergantz, G., Stair, K., Valencia, V., Gehrels, G., 2010, Timing constraints on building an intermediate plutonic arc crustal section: $\mathrm{U}-\mathrm{Pb}$ zircon geochronology of the Sierra Valle Fértil, Famatinian Arc, Argentina: Tectonics, 29, TC4002, doi:10.1029/2009TC002615.

Durand, F.R., 1996, La transición Precámbrico-Cámbrico en el sur de Sudamérica, in Baldis, B., Aceñolaza, F. (eds), Early Paleozoic evolution in NW Gondwana: Universidad Nacional de Tucumán, Argentina, Serie Correlación Geológica, 12, 195-205.

Escayola, M.P., Pimentel, M.M., Armstrong, M., 2007, Neoproterozoic backarc basin: Sensitive high-resolution ion microprobe $\mathrm{U}-\mathrm{Pb}$ and Sm-Nd isotopic evidence from the Eastern Pampean Ranges, Argentina: Geology, 35, 495-498.

Escayola, M.P., van Staal, C.R., Davis, W.J., 2011, The age and tectonic setting of the Puncoviscana Formation in northwestern Argentina: an accretionary complex related to Early Cambrian closure of the Puncoviscana Ocean and accretion of the Arequipa-Antofalla block: Journal of South American Earth Sciences, 32, 438-459.

Fantini, R., Gromet, P., Simpson, C., Northrup, C.J., 1998, Timing of hightemperature metamorphism in the Sierras Pampeanas of Córdoba, Argentina: implications for aLaurentia-Gondwana Interactions, in $\mathrm{X}$ Congreso Latino Americano de Geología y VI Congreso Nacional de Geología Económica, Buenos Aires, Argentina: Buenos Aires, Argentina, Sociedad Geológica Argentina, Actas II, 388-392. 
Fedo, C.M., Nesbitt, H.W., Young, G.M., 1995, Unraveling the effects of potassium metasomatism in sedimentary rocks and paleosols, with implications for paleoweathering conditions and provenance: Geology, 23, 921-924.

Fedo, C.M., Eriksson, K.A., Krogstad, E.J., 1996, Geochemistry of shales from the Archean $(\sim 3.0 \mathrm{Ga})$ Buhwa Greenstone Belt, Zimbabwe: implications for provenance and source-area weathering: Geochimica et Cosmochimica Acta, 60, 1751-1763.

Floyd, P.A., Leveridge, B.E., 1987, Tectonic environment of the Devonian Gramscatho basin, south Cornwall: framework mode and geochemical evidence from turbiditic sandstones: Journal of the Geological Society, 144, 531-542.

Floyd, P.A., Shail, R., Leveridge, B. E., Franke, W., 1991, Geochemistry and provenance of Rhenohercynian synorogenic sandstones: implications for tectonic environment discrimination, in Morton, A.C., Todd, S.P., Haughton, P.D.W. (eds.), Developments in Sedimentary Provenance Studies, Special Publication: London, United Kingdom, Journal of the Geological Society of London, 57, 173-188.

García, D, Fonteilles, M., Moutte, J., 1994, Sedimentary fractionations between $\mathrm{Al}, \mathrm{Ti}$, and $\mathrm{Zr}$ and the genesis of strongly prealuminous granites: Journal of Geology, 102, 411-422.

Girty, G.H., Hanson, A.D., Knaack, C., Johnson, D., 1994, Provenance determined by REE, Th, and Sc analyses of metasedimentary rocks, Boyden Cave roof pendant, central Sierra Nevada, California: Journal of Sedimentary Research, 64, 68-73.

González, O. E., Viruel, M. E., Mon, R., Tchilinguirian, P., Barber, E., 2000, Hoja Geológica 2766-II San Miguel de Tucumán, escala 1:250000, Buenos Aires, Argentina, Servicio Geológico Argentino, Programa Nacional de Cartas Geológicas de la República Argentina, 1 mapa, Boletín 245.

Gosen, W. von, Prozzi, C., 2010, Pampean deformation in the Sierra Norte de Córdoba, Argentina: Implications for the collisional history at the western pre-Andean Gondwana margin, Tectonics, 29, TC2012, doi: 10.1029/2009TC002580.

Gromet, L.P., Dymek, R.R., Haskin, L.A., Korotev, R.L., 1984, The "North American Shale Composite": Its compilation, major, and trace element characteristics: Geochimica et Cosmochimica Acta, $48,2469-2482$.

Gromet, L.P., Simpson, C., 1999, Age of the Paso del Carmen pluton and implications for the duration of the Pampean Orogeny, Sierras de Córdoba, Argentina, in XIV ${ }^{\circ}$ Congreso Geológico Argentino, Salta, Argentina: Salta, Argentina, Victor Manuel Hanne, 14, 149-151.

Gromet, L.P., Simpson. C., 2000, Cambrian orogeny in the Sierras Pampeanas, Argentina: ridge subduction or continental collision?, in Geological Society of America Annual Meeting, Reno, Nevada: Boulder, Colorado, Geological Society of America, Abstracts with Programs, 32, A450.

Gu X.X., 1996a, Geochemical characteristics of sediments and tectonic setting analysis of sedimentary basins, in Developments in Geosciences and Technology, 1995. Press of the University of Geosciences of China, Beijing, 205-212.

Gu, X.X., 1996b, Geochemical characteristics of the Triassic Tethys sediments in NW-Sichuan and its implications to the weathering conditions in source regions: Mineral Petrology and Geochemistry Bulletin, 15, 23-27.

Haines, P.W., Hand, M., Sandiford, M., 2001, Paleozoic synorogenic sedimentation in central and northern Australia: a review of distribution and timing with implications for the evolution of intercontinental orogens: Australian Journal of Earth Sciences, 48, 911-928.

Hauser, N., Matteini, M., Omarini, R.H., Pimentel, M.M., 2011, Combined $\mathrm{U}-\mathrm{Pb}$ and $\mathrm{Lu}-\mathrm{Hf}$ isotope data on turbidites of the Paleozoic basement of NW Argentina and petrology of associated igneous rocks: Implications for the tectonic evolution of western Gondwana between 560 and 460 Ma: Gondwana Research, 19, 100-127.

Hofmann, A.W., 1988, Chemical differentiation of the Earth: the relationship between mantle, continental crust, and oceanic crust: Earth and Planetary Science Letters, 90, 297-314.
Iannizzotto, N.F., Rapela, C.W. Baldo, E. G.A. Galindo, C., Fanning, C.M., Pankhurst, R.J., 2013, The Sierra Norte-Ambargasta batholith: Late Ediacaran-Early Cambrian magmatism associated with Pampean transpressional tectonics: Journal of South American Earth Sciences, v. 42, 127-143.

Jezek, P., 1990, Análisis sedimentológico de la Formación Puncoviscana entre Tucumán y Salta, in Aceñolaza, F.G., Miller, H., Toselli, A.J. (eds.), El Ciclo Pampeano en el Noroeste Argentino, Serie Correlación Geológica: San Miguel de Tucumán, Argentina, Universidad Nacional de Tucumán. 9-36.

Jezek, P., Miller, H., 1986, Deposition and facies distribution of turbiditic sediments of the Puncoviscana Formation (Upper Precambrianlower Cambrian) within the basement of the NW Argentine Andes: Zentralblatt für Geologie und Paläontologie, 9-10, 1235-1244.

Jezek, P., Miller, H., 1987, Petrology and facies analysis of turbiditic sedimentary rocks of the Puncoviscana through (Upper Precambrianlower Cambrian) in the basement of the NW Argentine Andes, in Garry D. McKenzie, (ed.) Gondwana Six: Structure, tectonics, and geophysics: Washington, D.C., U.S.A., Geophysical Monograph, 287-293.

Jezek, P., Willner, A.P., Aceñolaza, F.G., Miller, H., 1985, The Puncoviscana trough - a large basin of Late Precambrian to Early Cambrian age on the Pacific edge of the Brazilian shield: Geologische Rundschau, 74, 573-584.

Jordan, T.E., Allmendinger, R.W., 1986, The Sierras Pampeanas of Argentina: a modern analogue of Rocky Mountain foreland deformation: American Journal of Science, 286, 737-764.

Krol, M.A., Simpson, C., 1999, Thermal history of the eastern Sierras Pampeanas accretionary prism rocks, constraints from ${ }^{40} \mathrm{Ar} /{ }^{39} \mathrm{Ar}$ mica data, in Geological Society of America Annual Meeting, Denver, Colorado, Abstracts with Programs: Boulder, Colorado, U.S.A., Geological Society of America, 31, 114-115.

Li, Q., Liu, S., Han, B., Zhang, J., Chu, Z., 2005, Geochemistry of metasedimentary rocks of the Proterozoic Xingxingxia complex: implications for provenance and tectonic setting of the eastern segment of the Central Tianshan Tectonic Zone, northwestern China: Canadian Journal of Earth Sciences, 42, 287-306.

Lira, R., Millone, H. A., Kirschbaum, A.M., Moreno, R.S., 1997, Calcalkaline arc granitoid activity in the Sierra Norte-Ambargasta Ranges, Central Argentina: Journal of South American Earth Sciences, 10, 157-177.

Lork, A., Miller, H., Kramm, U., Grauert, B., 1990, Sistemática U-Pb de circones detríticos de la Formación Puncoviscana y su significado para la edad máxima de sedimentación en la Sierra de Cachi (Provincia de Salta, Argentina), in Aceñolaza, F.G., Miller, H., Toselli, A.J. (eds.), El Ciclo Pampeano en el Noroeste Argentino, Serie Correlación Geológica: San Miguel de Tucumán, Argentina, Universidad Nacional de Tucumán, 4,199-208.

Lucassen, F., Becchio, R., Wilke, H.G., Franz, G., Thirlwall, M.F., Viramonte, J., Wemmer, K., 2000, Proterozoic-Paleozoic development on the basement of the Central Andes (18-26 $\left.{ }^{\circ} \mathrm{S}\right)-\mathrm{a}$ mobile belt of the South America craton: Journal of South American Earth Sciences, 13, 697-715.

Maidment, D.W., Williams, I.S., Hand, M., 2007, Testing long-term patterns of basin sedimentation by detrital zircon geochronology, Centralian superbasin, Australia: Basin Research, 19, 335-360.

Mazur, S., Aleksandrowski, P., Turniak, K., Krseminski, L., Mastalerz, K., Górecka-Nowak, A., Kurowski, L., Krzywiec, P., Zelazniewicz, A., Fanning, M.C., 2010, Uplift and late orogenic deformation of the Central European Variscan belt as revealed by sediment provenance and structural record in the Carboniferous foreland basin of western Poland: International Journal of Earth Sciences (Geologische Rundschau), 99, 47-64.

McCann, T., Saintot, A., 2003, Tracing tectonic deformation using the sedimentary record: an overview, in McCann, Saintot, A. (eds.), Tracing tectonic deformation using the sedimentary record: London, United Kingdon, Geological Society of London, Special Publication, $208,1-28$. 
McLennan, S.M., 1989, Rare earth elements in sedimentary rocks: influence of provenance and sedimentary processes: Reviews in Mineralogy, $21,169-200$.

McLennan, S.M., 2001, Relationships between the trace element composition of sedimentary rocks and upper continental crust: Geochemistry Geophysics Geosystems, 2, 1021-1045.

McLennan, S.M, Taylor S.R., 1991, Sedimentary rocks and crustal evolution: tectonic setting and secular trends: Journal of Geology, 99, 1-21.

McLennan, S.M., Taylor, S.R., Eriksson, K.A., 1983, Geochemistry of Archean shales from the Pilbara Supergroup, Western Australia: Geochimca et Cosmochimica Acta, 47, 1211-1222.

McLennan, S.M., Taylor, S.R., McCulloch, M.T., Maynard, J.B., 1990, Geochemical and Nd-Sr isotopic composition of deep-sea turbidites: crustal evolution and plate tectonic associations: Geochimica et Cosmochimica Acta, 54, 2015-2050.

McLennan, S.M., Hemming, S., McDaniel, D.K., Hanson, G.N., 1993, Geochemical approaches to sedimentation, provenance and tectonics, in Johnsson, M.J., Basu, A. (eds.), Processes controlling the composition of clastic sediments, Geological Society of America Special Publications: Boulder, Colorado, U.S.A., Geological Society of America, 284, 21-40.

McLennan, S.M., Hemming, S. R., Taylor, S.R., Eriksson, K.A., 1995 Early Proterozoic crustal evolution: geochemical and $\mathrm{Nd}-\mathrm{Pb}$ isotopic evidence from metasedimentary rocks, southwestern North America: Geochimica et Cosmochimica Acta, 59, 1153-1177.

Meinhold, G., Kostopoulos, D., Reischmann, T., 2007, Geochemical constraints on the provenance and depositional setting of sedimentary rocks from the islands of Chios, Inousses, and Psara, Aegean Sea, Greece: Implications for the evolution of Palaeotethys: Journal of the Geological Society, London, 164, 1145-1163.

Mon, R., Hongn, F.D., 1991, The structure of the Precambrian and lower Paleozoic basement of the Central Andes between $22^{\circ}$ and $32^{\circ} \mathrm{S}$ Lat.: Geologische Rundschau, 80, 745-758.

Murra, J., Baldo, E., Galindo, C., Casquet, C., Pankhurst, R., Rapela, C., Dahlquist, J., 2011, Sr, C and O isotope composition of marbles from the Sierra de Ancasti, Eastern Sierras Pampeanas, Argentina: age and constraints for the Neoproterozoicelower Paleozoic evolution of the proto-Gondwana margin: Geologica Acta, 9, 79-92.

Nesbitt, H.W., Young, G.M., 1982, Early Proterozoic climates and plate motions inferred from major element chemistry of lutites: Nature, 299, 715-717.

Nesbitt, H.W., Young, G.M., 1984, Prediction of some weathering trends of plutonic and volcanic rocks based on thermodynamic and kinetic considerations: Geochimica et Cosmochimica Acta, 48, 1523-1534.

Nesbitt, H.W., Young, G.M., 1989, Formation and diagenesis of weathering profiles: Journal of Geology, 97, 129-147.

Omarini, R.H., Sureda, R.J., Gotze, H.J., Seilacher, A., Pfluger, F., 1999, Puncoviscana folded belt in northwestern Argentina: testimony of Late Proterozoic Rodinia fragmentation and pre-Gondwana collisional episodes: International Journal of Earth Sciences, 88, 76-97.

Otamendi, J.E., Ducea, M.N., Bergantz, G.W., 2012, Geological, Petrological, and Geochemical Evidence for Progressive Construction of an Arc Crustal Section, Sierra de Valle Fértil, Famatinian Arc, Argentina: Journal of Petrology, 53, 4.

Pankhurst, R.J., Rapela. C.W., Saavedra, J., 1997, The Sierras Pampeanas of NW Argentina-growth of the Pre-Andean margin of Gondwana: European Union of Geosciences, Abstract Supplement I, Terra Nova, 9, 1-162.

Pankhurst, R.J., Rapela, C.W., Saavedra. J., Baldo, E., Dahlquist, J., Pascua, I., Fanning, C.M., 1998, The Famatinian magmatic arc in the central Sierras Pampeanas: an Early to Mid-Ordovician continental arc on the Gondwana margin, in Pankhurst R.J., Rapela, C.W. (eds.), The proto-Andean Margin of Gondwana: London, United Kingdon, Special Publication of the Geological Society of London, 142, 343-367.

Pankhurst, R.J. Rapela, C.W. \& Fanning, C.M., 2000, Age and origin of coeval TTG, I- and S-type granites in the Famatinian belt of NW
Argentina: Transactions of the Royal Society of Edinburgh: Earth Science, 91, 151-168.

Piñán-Llamas, A., Simpson, C., 2006, Deformation of Gondwana margin turbidites during the Pampean orogeny, north-central Argentina: Geological Society of America Bulletin, 118, 1270-1279.

Piñán-Llamas, A., Simpson, C., 2009, Primary structure influence on compositional banding in psammites: Examples from the Puncoviscana Formation, North-central Argentina: Journal of Structural Geology, 31, 55-71.

Porto, J.C., Fernández, R.I., Carrión, M.H., 1990, Calizas y dolomías de la Formación Puncoviscana, in Aceñolaza, F.G., Miller, H., Toselli, A.J. (eds.), El Ciclo Pampeano en el Noroeste Argentino, Serie Correlación Geológica: San Miguel de Tucumán, Argentina, Universidad Nacional de Tucumán, 4, 37-52.

Ramos, V.A., 1988, Late Proterozoic-Early Paleozoic of South America - a Collisional History: Episodes, 11, 168-174.

Ramos, V., 1999, Las provincias geológicas del territorio argentino, in Caminos, R. (ed.), Geología Argentina: Buenos Aires, Argentina, Servicio GeológicoMinero Argentino, Anales 29, 41-96.

Ramos, V.A., 2008, The basement of the Central Andes: the Arequipa and related Terranes: Annual Review of Earth and Planetary Sciences, 36, 289-324.

Ramos, V.A., 2009, Anatomy and global context of the Andes: Main geologic features and the Andean orogenic cycle, in Kay, S.M., Ramos, V.A., Dickinson, W.R., (eds.), Backbone of the Americas: Shallow Subduction, Plateau Uplift, and Ridge and Terrane Collision: Boulder, Colorado, U.S.A., Geological Society of America, Memoir 204, 31-65.

Ramos, V.A., Jordan, T.E., Allmendinger, R.W. Mpodozis, C., Kay, S.M., Cortes, J. M., Palma, M., 1986, Paleozoic terranes of the central Argentine-Chilean Andes: Tectonics, 5, 855-880.

Ramos, V.A., Escayola, M., Mutt, D.I., Vujovich, G.I., 2000, Proterozoicearly Paleozoic ophiolites of the Andean basement of southern South America, in Dilek, Y., Moores, E.M., Elthon, D., Nicolas, A. (eds.), Ophiolites and oceanic crust: new insights from field studies and the Ocean Drilling Program: Boulder, Colorado, U.S.A., Geological Society of America, Special Paper, 349,331-349.

Ramos, V.A., Cristallini, E.O., Perez, D.J., 2002, The Pampean flat-slab of the Central Andes: Journal of South American Earth Sciences, 15, 59-78.

Rapela, C.W., Pankhurst, R.J., Casquet, C., Baldo, E.G., Saavedra, J., Galindo, C., Fanning, C. M., 1998, The Pampean Orogeny of the south proto-Andes: evidence for Cambrian continental collision in the Sierras de Córdoba, in Pankhurst, R.J., Rapela, C.W. (eds.), The proto-Andean Margin of Gondwana: London, United Kingdom, Special Publication of the Geological Society,142,181-217.

Rapela, C.W., Toselli, A., Heaman, L., Saavedeu, L., 1990, Granite plutonism of the Sierras Pampeanas; an inner eordilleran Palaeozoic arc in the southern Andes, in May, S.M., Wela, C.W. (eds.), Plutonism from Antartica to Alaska: Boulder, Colorado, U.S.A., Geological Society of America Special Paper, 241, 77-99.

Rapela, C.W., Baldo. E.G., Pankhurst, R.J., Saavedra, J., 2002, Cordierite and Leucogranite Formation during Emplacement of Highly Peraluminous Magma: the El Pilón Granite Complex (Sierras Pampeanas, Argentina): Journal of Petrology, 43, 1003-1028.

Rapela, C.W., Pankhurst, R. J., Casquet, C., Fanning, C.M., Baldo, E.G., Gonzales-Casado J.M., Galindo. C., Dahlquist, J., 2007, The Rio de la Plata craton and the assembly of SW Gondwana: Earth Sciences Review, 83, 49-82.

Roser, B.P., Korsch, R.J., 1985, Plate tectonics and geochemical composition of sandstones: A discussion: Journal of Geology, 93, 81-84.

Roser, B.P., Korsch, R.J., 1986, Determination of tectonic setting of sandstone-mudstone suites using $\mathrm{SiO} 2$ content and $\mathrm{K} 2 \mathrm{O} / \mathrm{Na} 2 \mathrm{O}$ ratio: Journal of Geology, 94, 635-650.

Roser, B.P., Korsch, R.J., 1988, Provenance signatures of sandstonemudstone suites determined using discriminant function analysis of major-element data: Chemical Geology, 67, 119-139. 
Roser, B.P., Cooper, R.A., Nathan, S., Tulloch, A.J., 1996, Reconnaissance sandstone geochemistry, provenance, and tectonic setting of the lower Paleozoic terranes of the West Coast and Nelson, New Zealand: Journal of Geology and Geophysics, 39, 1-16.

Saavedra, J., Toselli, A., Rossi, J., Pellitero, E., Durand, F., 1998, The Early Paleozoic magmatic record of the Famatina System: a review, in Pankhurst, R.J., Rapela, C.W. (eds.), The proto-Andean Margin of Gondwana: London, United Kingdom, Special Publications of the Geological Society, 142, 283-295.

Sánchez, M.C., Salfity, J.A., 1999, La cuenca cámbrica del Grupo Mesón en el noroeste argentino: Desarrollo estratigráfico y paleogeográfico: Acta Geológica Hispánica, 34, 123-139.

Schwartz, J.J., Gromet, L.P., 2004, Provenance of a late Proterozoicearly Cambrian basin Sierras de Córdoba, Argentina: Precambrian Research, 129, 1-21.

Schwartz, J.J., Gromet, L.P., Miró, R., 2008, Timing and duration of the calc-alkaline arc of the Pampean Orogeny: implications for the Late Neoproterozoic to Cambrian evolution of Western Gondwana: Journal of Geology, 116, 39-61.

Shaw, D.M., 1968, A review of K-Rb fractionation trends by covariance analysis: Geochimica et Cosmochimica Acta, 32, 573-601.

Siegesmund, S., Steenken, A., Martino, R.D., Wemmer, K., Lopez de Luchi, M., Frei, R., Presnyakov, S., Guereschi, A., 2010, Time constraints on the tectonic evolution of the Eastern Sierras Pampeanas (Central Argentina): International Journal of Earth Sciences, 99, 1199-1226.

Simpson, C., Law, R.D.W., Gromet, L.P., Miro, R., Northrup, C.J., 2003, Paleozoic deformation in the Sierras de Córdoba and Sierra de Las Minas, eastern Sierras Pampeanas, Argentina: Journal of South American Earth Sciences, 15, 749-764.

Sims, J.P., Ireland, T.R., Camacho, A., Lyons, P., Pieters, P.E., Skirrow, R.G., Stuart-Smith, P.G., Miró, R., 1998 U-Pb, Th-Pb, and Ar-Ar geochronology from the southern Sierras Pampeanas, Argentina: implications for the Palaeozoic tectonic evolution of the western Gondwana margin, in Pankhurst, R.J., Rapela, C.W. (eds.), The proto-Andean Margin of Gondwana: London, United Kingdom, Special Publications of the Geological Society, London, 142, 259-281.

Steenken, A., López de Luchi, M.G., Siegesmund, S., Wemmer, K., Pawlig, S., 2004, Crustal provenance and cooling of the basement complexes of the Sierra de San Luis: an insight into the tectonic history of the proto-Andean margin of Gondwana: Gondwana Research, 7, 1171-1195.

Steenken A., Siegesmund S., López de Luchi M.G., Frei R., Wemmer K., 2006, Neoproterozoic to Early Palaeozoic events in the Sierra de San Luis: implications for the Famatinian geodynamics in the Eastern Sierras Pampeanas (Argentina): Journal of the Geological Society, 163, 965-982.

Steenken, A., Wemmer, K., Martino, R.D., López de Luchi, M.G., Guereschi, A., Siegesmund, S., 2010, Post-Pampean cooling and the uplift of the Sierras Pampeanas in the west of Córdoba (Central Argentina): Neues Jahrbuch für Geologie und Paläontologie , 256, 235-255.

Steenken, A., López de Luchi, M.G., Martínez-Dopico, C., Drobe, M., Wemmer, K., Siegesmund, S., 2011, The Neoproterozoic-early Paleozoic metamorphic and magmatic evolution of the Eastern Sierras Pampenas: an overview: International Journal of Earth Sciences (Geologische Rundschau), 100, 465-488.

Taylor, S.R., McLennan, S.M., 1981, The composition and evolution of the continental crust: Rare Earth element evidence from sedimentary rocks: Philosophical Transactions of the Royal Society of London, 301, 381-399.

Taylor, S.R., McLennan, S.M., 1985, The continental crust: its composition and evolution: Oxford, United Kingdom, Blackwell Scientific Publications $312 \mathrm{p}$
Taylor, S.R., McLennan, S.M., 1995, The geochemical evolution of the continental crust: Reviews of Geophysics, 33, 241-265.

Thomas, W., Astini, R., 2003, Ordovician accretion of the Argentine Precordillera terrane to Gondwana: a review: Journal of South American Earth Sciences, 16, 67-79.

Toselli, A.J., 1990, Metamorfismo del ciclo Pampeano en el Noroeste Argentino, in Aceñolaza, F.G., Miller, H., Toselli, A.J. (eds.), El Ciclo Pampeano en el Noroeste Argentino, Serie Correlación Geológica: Tucumán, San Miguel de Tucumán, Argentina, Universidad Nacional de Tucumán, 4, 181-197.

Toselli, A.J., Rossi de Toselli, J.N., Rapela, C.W., 1978, El basamento metamórfico de la Sierra de Quilmes, República Argentina: Revista de la Asociación Geológica Argentina, 33, 105-121.

Toselli, A., Rossi de Toselli, J.N., 1983a, Metamorfismo de la Formación Puncoviscana en las provincias de Salta y Tucumán, Argentina, in $\mathrm{V}$ Congreso Latinoamericano de Geología, Buenos Aires, Argentina, 2, 37-52.

Toselli, A., Rossi de Toselli, J. N., 1983b, Controles de metamorfismo y deformación en las parametamorfitas de las Cumbres de San Javier, Tucumán: Revista de la Asociación Geológica Argentina, $38,137-147$.

Turner, J.C.M., 1960, Estratigrafía de la Sierra de Santa Victoria: Academia Nacional de Ciencias de Córdoba, Argentina, 49, 163-196.

Verdeccia, S.O., Baldo, E.G., 2010, Geoquimica y procedencia de los metasedimentos ordovicicos del complejo metamorfico La Cebila, provincia de La Rioja, Argentina: Revista de Ciencias Geológicas, $27,97-111$.

Willner, A.P., 1983, Evolución tectónica, in Aceñolaza, F.G., Miller, H., Toselli, A. (eds.), La Geología de la Sierra de Ancasti: Munich, Germany, Munster Forschungen zur Geologie und Paläontologie, $59,157-187$.

Willner, A.P., 1990, División tectonometamórfica del basamento del noroeste Argentino, in Aceñolaza, F.G., Miller, H., Toselli, A.J. (eds.) El Ciclo Pampeano en el Noroeste Argentino: Serie Correlación Geológica: San Miguel de Tucumán, Argentina, Universidad Nacional de Tucumán, 4,113-159.

Willner, A.P., Miller, H., 1982, Polyphase metamorphism in the Sierra de Ancasti (Pampean Ranges, NW Argentina) and its relation to deformation, en V Congreso Latinoamericano de Geología: Buenos Aires, Argentina, Sociedad Geológica Argentina, 3, 441-455

Willner, A.P., Miller, H., 1985, Structural Division and Evolution of the lower Paleozoic Basement in the NW Argentine Andes: Zentralblatt für Geologie und Paläontologie, 1, 1245-1255.

Willner, A.P., Miller, H., Jezek, P., 1985, Geochemical features of an Upper Precambrian-lower Cambrian greywacke/pelite sequence (Puncoviscana trough) from the basement of the NW-Argentine Andes: Neues Jahrbuch für Geologie und Paleontologie, 8, 498-512.

Zimmermann, U., 2005, Provenance studies of very low to low-grade metasedimentary rocks of the Puncoviscana complex, northwest Argentina, in Vaughan, A.P.M., Leat, P.T., Pankhurst, R.J. (eds.), Terrane processes at the margin of Gondwana: London, United Kingdom, Special Publications of the Geological Society, London, 246, 381-416.

Manuscript received: June 23, 2012.

Corrected manuscript received: October 23, 2012.

Manuscript accepted: October 26, 2012. 